\author{
Danuta Opacka-Walasek \\ Uniwersytet Śląski
}

\title{
Nikifor i „Genko-wariat”. Wgląd w ekfrastyczne transgresje polsko-bułgarskie
}

Lecący do Bułgarii w 1962 roku $^{1}$ Nikifor miał na pokładzie samolotu powiedzieć do Mariana Włosińskiego: „Chyba lecę do nieba, ale świętych nie widać”.

1 Czy podróż Nikifora do Bułgarii wiązała się ze zorganizowaną tam wystawą jego prac, czy był to wyjazd wakacyjny (wraz z Włosińskim, który opiekował malarzem od 1960 roku do jego śmierci, w tym od 1962 roku formalnie, jako prawny kurator), nie zostało wiarygodnie ustalone. Źródła polskie są w tej kwestii niejednoznaczne: tylko odnotowują fakt „wystawy” lub „wczasów” albo pomijają faktograficzne adnotacje o takim wydarzeniu, albo umieszczają krótką wzmiankę na temat bułgarskiej ekspozycji w kontekście oficjalnego wydania, wówczas sześćdziesięciosiedmioletniemu Nikiforowi, aktu urodzenia i dowodu osobistego w 1962 roku. Do tego czasu kłopotliwy Łemko nie posiadał żadnych dokumentów, a wyjechać bez nich za granicę nie mógł. Napomknienia o jego „bułgarskiej wystawie” funkcjonują w kilkudziesięciu tekstach, powielane bez uwiarygodniających odsyłaczy, zaś w Bułgarii dotąd nie udało mi się potwierdzić, czy istotnie odbyło się (lub było przygotowywane) takie wydarzenie. Nie ma też doniesień o owej niepewnej ekspozycji pośród innych wystaw zagranicznych Nikifora w okresie socjalizmu. Andrzej Banach, podając miejsca, w których wraz z żoną Ellą promowali od lat czterdziestych sztukę nieznanego jeszcze Nikifora, pisze: „Nasza przyjaźń z Nikiforem, rozpoczęta spotkaniem z nim w roku 1947, doprowadziła do pokazania go w ciągu niecałych trzech lat w dziesięciu miastach Europy Zachodniej i Małej Azji. Był w Paryżu, Amsterdamie, w Brukseli, w Liege, w Hajfie, w Baden-Baden, we Frankfurcie nad Menem, w Hanowerze, w Bazylei, i znowu w Paryżu. Był też w Rzymie, w Knokke-Le-Zoute, 
Ta anegdota, przywoływana w tekstach o Epifaniuszu Drowniaku, wobec kierunku podróży wybrzmiewa sensami najpewniej przez niego niezamierzonymi. Natrętna jest myśl, że choć Łemko zmierzał ku firmamentowi prawosławnemu, najbliższemu jego rdzennej religii, to tak nad Polską, jak nad Bułgarią święci wycofali się w wyższe rejony - „niebo” urządzane w tamtych latach przez ustrój nie mogło być dla nich miejscem przychylnym. Zarazem w obu krajach panowały równie niesprzyjające warunki dla twórców podobnych Nikiforowi: obciążonych stygmatyzującą odmiennością ludzi-dziwów o unikatowym talencie, którzy ani mogli, ani chcieli się stowarzyszać z preferowanymi tendencjami. W niezgodzie z nimi, a przez wiele lat równolegle z Nikiforem (1895-1968) malował w Bułgarii Genko Genkov (1923-2006)².

w Wiedniu, w Chicago, w Londynie, nie licząc pomniejszych ekspozycji zagranicznych” (Banach 1984: 12). Niewykluczone, że uogólnienie „pomniejszych ekspozycji zagranicznych”, jeśli dotyczy lat późniejszych, może obejmować któreś z miast bułgarskich. Wzmianki na temat tamtej podróży malarza wskazują rok 1962, rzadziej 1963. Tę ostatnią datę sugeruje m.in. tekst w archiwalnym numerze „Przekroju” (nr 42, 20.10.1963). Jest to list Zbigniewa K. Rogowskiego, korespondenta „Przekroju” z Hollywood, a wcześniej współzałożyciela czasopisma, w którym pisze: „Przed miesiącem, w towarzystwie Mariana Włosińskiego swego opiekuna, plastyka mieszkającego w Krynicy, poleciał on do Bułgarii na dwutygodniowy wypoczynek (wyróż. - D.O.W.). Była to bodaj pierwsza podróż Nikifora za granicę, jeśli nie liczyć odbytej przed wojną pieszej wędrówki (boso) na odpust do Bardiejowa, leżącego po czeskiej stronie. Nikifor, poruszony perspektywą podniebnego wojażu, zaczął malować, jeszcze PRzed odlotem do Bułgarii, i Warszawę, i samoloty”. Wydrukowany w „Przekroju” list Rogowskiego opatrzony jest adekwatnym rysunkiem Nikifora (Warszawa i samoloty) oraz czterema zdjęciami. Wobec dotąd nieodnalezionych faktograficznych potwierdzeń i, z jednej strony, licznych legend otaczających życie Nikifora, z drugiej strony, funkcjonowania polityki (nie tylko) kulturalnej i informacyjnej w ówczesnych warunkach ustrojowych, a także nieoczywistych losów, terminowych i publikacyjnych, korespondencji Rogowskiego z „Przekrojem”, trudno jednoznacznie orzec, kiedy dokładnie - i czy w związku z wystawą - miała miejsce ta podróż. Pewne jest, że była: dowodzą tego, poza monografistami twórczości Nikifora (jak Banachowie, mecenasi Nikifora, do których książek najczęściej odsyłają pozostali autorzy) i wspomnieniami osób z jego kręgu, obrazy artysty (m.in. Nikifor z Marianem Włosińskim na wielbładach $w$ Bułgarii) oraz fotografie.

2 Genko Ivanov Genkov, żywa legenda bułgarskiej bohemy, uchodzi za jej promesę do światowego malarstwa. W przeciwieństwie do Nikifora, wykształcony i o zupełnie innym życiowym starcie: urodzony $\mathrm{w}$ inteligenckiej rodzinie, $\mathrm{z}$ ukończonym liceum półklasycznym, ze studiami na Akademii Sztuk Pięknych w Sofii. Nieustannie w konflikcie: z samym sobą, z malarskimi tendencjami, z systemem, władzą nade wszystko. Dysydent, wielokrotnie izolowany w bułgarskich obozach pracy i szpitalach psychiatrycznych. Niebywale utalentowany, opisywany jest jako równie kontrowersyjny, pełen 
Twórczość obu artystów oraz postacie Nikifora i Genkova - kłopotliwych „odmieńców”, którzy przez gros życia byli marginalizowani w swoich krajach stała się przedmiotem licznych tekstów ekfrastycznych ${ }^{3}$. Ich literackie, para-

sprzeczności człowiek o dramatycznej biografii. Urodzony 31 stycznia 1923 roku w wiosce Choba w okręgu płowdiwskim, dorastał w Burgas. W dzieciństwie rozpoznany jako talent przez prof. Iwana Lazarowa, jeszcze przed maturą wystawia pierwsze prace. W 1943 roku dostaje się na Akademię Sztuk Pięknych, studia finalizuje w 1948 roku dyplomem u prof. Deczko Uzunowa. Po studiach zatrudniony jako retuszer, później w fabryce bakelitu; rzuca pracę i przez 10 lat funkcjonuje w Sofii bez meldunku, mieszkania, zatrudnienia. Utrzymuje się, jak Nikifor, ze sprzedaży za bezcen swoich obrazów. Jest gwałtownikiem, skandalistą o - znów legendarnie - silnej i bezkompromisowej osobowości. Trzykrotnie więziony w bułgarskich obozach pracy, w tym, po powstaniu węgierskim 1956 roku, w wyjątkowo ciężkim obozie na wyspie Belene, przymusowo izolowany w szpitalach psychiatrycznych, ciągle maluje. Jego obrazy robią karierę światową, sprzedawane, wystawiane, także w czasie represji wobec artysty, w renomowanych galeriach bułgarskich i zagranicznych (m.in. stała ekspozycja w Muzeum Guggenheima w Nowym Jorku). Po latach oficjalnej bezdomności w 1966 roku uzyskuje mieszkanie w Sofii - to jego pierwszy tam meldunek. Nie zmienia jednak trybu życia: jest wciąż na ulicach, w knajpach, znany jako Genko-wariat, nieustannie eksperymentuje, wykrzykuje swoje poglądy, nie tylko polityczne. Wielu traktuje go jako wyniszczającego siebie, imponującego niezależnością geniusza. W latach siedemdziesiątych, za czasów Todora Żiwkowa, ma kilka wystaw w Sofii, jest nagradzany, otrzymuje poddasze, gdzie mieszka i maluje. W 1979 roku opuszcza stolicę, zamieszkuje w odosobnieniu, w małym domku z płyt wiórowych. W 1980 roku wyjeżdża do NRD, po powrocie znów zamknięty w szpitalu psychiatrycznym w Kurilo, potem w Moreno, ucieka i ukrywa się w Sliven w domu przyjaciela. W 1982 roku otrzymuje od Żiwkowa tytuł Honorowego Artysty, nagrodę państwową. W 1985 roku wyjeżdża na dwa miesiące do Paryża. Przez lata osiemdziesiąte i dziewięćdziesiąte jest kilkakrotnie wystawiany w Sofii. Tworzy do śmierci (2006).

3 Wobec osłabienia kwalifikacji ekfrazy i rozmycia jej kryteriów gatunkowych oraz sugestii badaczy przedmiotu, że wielokrotnie bardziej zasadne jest wskazywanie na ekfrastyczność tekstów, posługuję się tą kategorią. Adam Dziadek pisze: „Jeśli chodzi o teksty współczesne, to warto zaznaczyć, że często spełniają one wyznaczniki ekfrazy jedynie po części i trafniej byłoby mówić o ich ekfrastyczności czy ich charakterze ekfrastycznym" (Dziadek 2006: 39-40). Podtrzymuje (i rozwija) tę uwagę Rozalia Słodczyk, autorka jednej z najnowszych monografii poświęconych tym zagadnieniom: Ekfraza, hypotypoza, przekład. Interferencje literatury i malarstwa $w$ prozie włoskiej i eseistyce polskiej XX (Słodczyk 2020). Wyłuszczając konotacyjno-denotacyjne zawirowania ekfrazy, konkluduje m.in.: „[Miewamy - D.O.W.] do czynienia i z opisem (choć często zredukowanym) plastycznego modelu, którym najczęściej jest obraz, i z prezentacją uwag prowokowanych przez dzieło sztuki oddziałujące na piszącego. [...] Artefakt w pewnym sensie staje się narzędziem w danej wypowiedzi - kiedyś umożliwiającym porwanie widza, apelującym do jego emocji i imaginacji, współcześnie w dużej mie- 
literackie, krytyczne (Riffaterre 1994) ${ }^{4}$ rejestry formalne są zróżnicowane, co pośrednio wskazuje i na istotność źródła inspiracji (artefaktów i ich twórców), i na fukcjonalizacje samej ekfrazy i ekfrastyczności we współczesnych artykulacjach. Jak o tym niejednokrotnie pisano, ekfraza, rozpięta pomiędzy mediacyjnością kodu werbalnego i bezpośredniością kodu wizualnego, uzyskiwała i wciąż uzyskuje nowe warianty, poszerza zakresy, zaś ujmowanie jej w różnych perspektywach metodologicznych może powodować pewną niedookreśloność, względność w mówieniu o relacjach słowno-obrazowych. O ewoluowaniu ekfrazy, a wraz z nim postępującej elastyczność stanowisk teoretycznych, pisze m.in. Rozalia Słodczyk:

Ekfraza określana jako współczesna od połowy xx wieku także doświadczyła zawirowań konotacyjno-denotacyjnych. Najpierw bowiem dominowały definicje, które zawężały jej zakres tematyczny (czasem radykalnie: ekfraza jako poetycki opis obrazu lub rzeźby). Ostatnie dwie dekady przyniosły z kolei falę prac, w których ekfrazę odnosi się do nowych obszarów, jak film czy muzyka. Często rozszerza się stosowalność terminu tak, że ogarnia on bez mała wszystkie teksty dotyczące sztuki, bez względu na charakter relacji międzyartystycznych (Słodczyk 2018: 365).

Adam Dziadek natomiast stawia retoryczne - i wiele mówiące o dynamiczności ekfrazy - pytanie w konkluzji jej wykładni:

rze pozwalającym wyrazić się osobowości autora, jego emocjonalnej i intelektualnej wrażliwości. Nacisk przeniósł się więc z odbiorcy i sugestywności ekfrazy na piszącego i subiektywny wymiar interpretacji dzieła plastycznego. W konsekwencji pojawia się rozdźwięk między starożytnym a współczesnym pojmowaniem ekfrazy. Posługujemy się dziś starym terminem, ale wyposażamy go w nowe znaczenie" (Słodczyk 2018: 365).

4 Opieram się na rozróżnieniu ekfraz wprowadzonym przez Michaella Riffaterre’a, a przypomnianym m.in. przez Słodczyk: „W odniesieniu do ekfrazy dzisiejszej sensowne byłoby stosowanie prostego podziału uwzględniającego funkcję ekfrazy. Taki jest projekt Riffaterre’a, który odróżnia ekfrazy literackie (w utworach literackich) od ekfraz krytycznych (w tekstach krytyków i historyków sztuki). Ekfraza krytyczna według badacza jest ufundowana na analizie formalnej swojego przedmiotu, formułuje sądy odnoszące się do konkretnych zasad estetycznych i reguł artystycznych. Z kolei ekfraza literacka - na idei obrazu („sur une idée du tableau”), na obrazie artysty („sur une image de l’artiste”), na językowym locus communis dotyczącym sztuki; niejednokrotnie odgrywa w utworze rolę symboliczną. W moim przekonaniu oba typy ekfrazy zawierają element subiektywnej interpretacji, choć indywidualna wrażliwość piszącego w większym stopniu ujawnia się bez wątpienia w ekfrazie literackiej” (Słodczyk 2018: 368). 
W tekstach współczesnych ekfrazy stanowią najczęściej rodzaj „zaszczepienia wizualnego", od którego zaczyna się swobodna narracja na temat danego dzieła czy też jego interpretacja. Nowoczesne ekfrazy „atakują statyczną ékphrasis” (Davidson), przedstawiony przedmiot traci stabilność i wymyka się opisowi. Doszło nawet do tego, że dzisiejsi pisarze, świadomi ograniczeń sztuki przedstawiania, stronią od tradycyjnych form opisu, ograniczając się do migotliwych przywołań dzieła sztuki. Ale co będzie dalej, jak opisywać bez opisu? (Dziadek 2018: 153).

W większości utworów, które poddaję tu interpretacji, mamy do czynienia właśnie z owym „wizualnym zaszczepieniem”: konkretny obraz bądź zsyntetyzowane w opisie elementy malarskiego stylu pobudzają autorów do szerszej refleksji egzystencjalnej, etycznej czy estetycznej. Taką kompozycję ma np. opowiadanie Jana Józefa Szczepańskiego Biskup jedzie przez morze (Szczepański 1983), któremu tytułu użyczył obraz Nikifora opisany w rozbudowanej, inicjalnej partii utworu. Szczepański z pieczołowitością i dużą sugestywnością uobecnia jego kompozycję i aurę, pisze ze znawstwem o kolorystyce, wewnętrznym świetle, rytmach, proporcjach, planach, charakterystycznych dla Nikifora konturach oddzielających elementy przedstawienia, odnosi się nawet do typowego dlań autografu, interpretując także jego wymowęs. Ten fragment to bez wątpienia ekfraza, zresztą wysokiej próby, dalszy ciąg opowiadania dotyczy zaś kwestii wiążących się oczywiście z estetyką, z malarstwem Nikifora i jego postacią, niemniej przybiera tonację egzystencjalno-etyczną i to ona dominuje w fabule, nadbudowana nad samą akcją. Także w ekfrastycznych tekstach ${ }^{6}$ odnoszących się do Genkova mamy najczęściej do czynienia z owym „wizualnym zaszczepieniem”, kiedy fragmenty utrzymane w formule ekfrazy wnoszą werbalną reprezentację jego płócien, pozostała (bardziej obszerna) część jest zaś ukierunkowana na inne, choć naturalnie się z nimi wiążące treści.

Poniższe rozważania, których przedmiotem są wybrane literackie i paraliterackie reprezentacje malarstwa oraz postaci Epifaniusza Drowniaka i Genki

5 „U samego dołu kompozycji widać napis rozciągnięty na całą jej szerokość, spełniający raczej dekoracyjną niż informacyjną rolę. Prawdopodobnie należy on do ikonograficznej konwencji, przeniesionej tu z ludowego drzeworytu. Słowa, nie oddzielone odstępami, tworzą jeden ciąg dziecinnie niezgrabnych kulfonów. «FRYKRYNICYWIESPAOMKIPOWIATNIRWCA». Jest to bełkot półanalfabety i półniemowy” (Szczepański 1983: 59).

6 Z wyjątkiem, rzecz jasna, ekfraz krytycznych, a więc artykułów historyków sztuki oraz monografii Jordana Jankova Bunt na tsvetovete (Bunt w kolorach), której metaforyczny tytuł kapitalnie oddaje i specyfikę barwnych eksperymentów Genkova, i jego postawę życiową, słynącą z kontestacji. 
Genkova, nie roszczą sobie ambicji metodologicznych. Zmierzam do naświetlenia analogii, które dostrzegam w tekstach inspirowanych fenomenami tych twórców, pośrednio zaś do ukazania paralelności zjawisk: Nikifora w Polsce i Genkova w Bułgarii. Przy całym zróżnicowaniu ich sztuki i osobowości, co wyraziste w tekstowych kreacjach, ujawnia się wiele miejsc wspólnych. Dotyczy to także rzeczywistości zewnątrzliterackiej, której realia (przetworzone artystycznie w literaturze czy ewokowane w wypowiedziach o innych rejestrach formalnych) stanowią naszkicowane tło bądź sprawczy kontekst, w którym umieszczone są postacie malarzy ${ }^{7}$. Kontekst ten ujawnia analogiczne mechanizmy systemu (nie zawsze z ludzką twarzą), warunkujące funkcjonowanie Nikifora i Genkova w swoich krajach, a z tym - oddziaływanie ich obrazów, wówczas tym mocniej uderzających oryginalnością i siłą wyrazu'. Wydaje się zarazem, że wybory tematologiczne i formalne autorów o nich piszących, to, jak profilują uobecnienia malarzy i co akcentują w subiektywnej wykładni ich sztuki, świadczy o wspólnotowym charakterze Europy Środkowej, także doświadczania jej „w cieniu imperium”. Pochodną tego doświadczenia bywają strategie konwersacyjne, wśród których znaczące miejsce zajmuje ekfrastyczność. Odnosząc się do ustaleń teoretycznych w tym zakresie, wybrane ich aspekty uruchamiam z nadzieją, że tym wielostronniej pozwolą naświetlić paralelę.

W „werbalnych reprezentacjach wizualnych reprezentacji” (Heffernan 1991: 299 $)^{9}$ inspirowanych sztuką Łemka i Bułgara uwyraźniany jest transgre-

7 W niektórych tekstach pojawiają się wręcz daty roczne, kiedy indziej sugestywne sygnały oddające atmosferę okresu, np. „Był to rok 1951. [...] Czasy nie sprzyjały dociekaniom tajemniczych źródeł sztuki” (Szczepański 1983: 62-63); „Nikt nie chciał wtedy mieć kłopotów z władzami [...]. Z powodu głośnych przekleństw Genko kilkakrotnie był zabierany do domu wariatów. Zwykle przed kolejnym zjazdem partii, bo takie wydarzenia go prowokowały i zaczynał jeszcze głośniej przeklinać publicznie Żiwkowa i rząd” (Ruenov, dostęp 2020).

8 Szczepański tak opisuje koloryt życia i sztuki, na tle której malarstwo Nikifora okazywało się fenomenem: „Żyliśmy wówczas w świecie sztuki dworskiej - tak rygorystycznym, że wygnano zeń nawet martwą naturę jako przejaw pustego (wrogiego właściwie, bo nie zdeklarowanego ideowo) estetyzmu. Był to rodzaj agitacyjnego koncernu, gdzie natchnienie spływało $z$ urzędniczych biurek w postaci instrukcji i formularzy i nazywało się „zamówieniem społecznym”. Otaczały nas portrety dygnitarzy, ceglane mury wznoszonych fabryk, entuzjastycznie napięte bicepsy i bagnety, ochoczo dobijające wroga. I nawet najzdolniejsi uderzali gorliwie w ton służalczej krzepy. Sucho było na tej patetycznej pustyni niewymownie" (Szczepański 1983: 63-64). Prawem nieodległej analogii można odnieść tę charakterystykę do bułgarskich warunków w dobie Genkova.

9 Słodczyk przypomina, że Heffernanowska formuła określająca ekfrazę uległa uściśleniu przez autora: „W swoim wcześniejszym artykule sformułował taką samą definicję, ale 
sywny potencjał ich malarstwa, podobnie jak temperamentu samych twórców, gdy w ekfrastycznych zbliżeniach proporcje pomiędzy „ideą obrazu” („sur une idée du tableau”) a obrazem artysty („sur une image de l'artiste”) są wyrównane, a czasami wręcz przeważają na rzecz wyeksponowania traumatycznych biografii i osobniczej specyfiki - narzucającej się w odbiorze, legendotwórczej. Potrzeba przełożenia jej na język plastycznych form (co tym oczywistsze w odniesieniu do Nikifora, że język konwencjonalny pozostawał z powodu wrodzonej wady poza jego zasięgiem), permanentne wykraczanie własną sztuką poza narzucane czy po prostu normatywne granice, $\mathrm{z}$ którymi z racji swojej szczególności tym mniej mogli się identyfikować, ujmowane jest w kategoriach fenomenu. Mobilizując (i warunkując) twórczość malarzy poza dominującą estetyką, w odbiorcach ich artefaktów, prócz wrażeń estetycznych, wywołuje to oddźwięk aksjologiczny, kierując myśl ku różnicy kontestującej homogeniczność, ku temu, co niesystemowe, a źródłowe, nieskażone, indywidualne. W opowiadaniu Biskup jedzie przez morze Szczepański kilkakrotnie akcentuje wartość owej różnicy. Uzyskawszy wyraz w malarskiej kompozycji, staje się ona ożywczym impulsem dla odbiorców, których codzienność to „mgła tępego przyzwyczajenia”, „spoufalenie z życiem tych, którzy kroczą w pośpiechu szerokim gościńcem" (Szczepański 1983: 63, 73). Dostrzeżona, aktywizuje potrzebę transgresji: wykroczenia poza „pustynię [...], gdzie tłumy drepczą pod pustym niebem, a zamiast modłów i zaklęć słychać komendy i krzyki sprzedawców. Równać krok! Kupuj pastę do zębów «Kalodont»!" (Szczepański 1983: 73). W opowiadaniu wielokrotnie podkreślany jest ów transgresywny impuls, wypływający z obrazów tak różniących się od „malarskiej panoramy tamtych lat” (Szczepański 1983: 63). Jego aksjologizację, a jest wręcz sakralizowany, konotuje tu dobór leksemów: „pielgrzymowałem do zjawiska, nie do człowieka”, „jak do żywej wody tęskniliśmy do prawdziwego słowa artysty”, „małe Nikiforowe źródełko [...] miało moc uzdrawiającą [...], obiecywało odrętwiałej duszy powrót do utraconych wymiarów istnienia" (Szczepański 1983: 63-64). Także w zapisanych reakcjach na malarstwo Genkova pojawiają się ewokacje transgresji:

Patrzę na jego płótna [...] i nie mogę uwierzyć w śmierć - ani moją, ani kogoś innego. Myślałem o tym wiele razy i teraz, patrząc na kolory, czuję to: nie ma końca - jest tylko nieskończoność, tylko bycie stąd i bycie spoza, jest tylko bycie poza bytem. A więc śmierć jest względna

zamiast «visual representation» użył wyrażenia «graphic representation», które nie było tak jednoznaczne i chwytliwe. Por. J.A.W. Heffernan Ekphrasis and Representation, s. 299" (Słodczyk 2018: 356, przyp. 15). 
i zwodnicza jak życie, a śmierć jako narodziny może być początkiem ${ }^{10}$ (Boczev, dostęp 2020).

W tekstowych kreacjach Nikifora i Genkova, samych ich osobowości i biograficznych uwikłań, niejednokrotnie akcenty również zostają położone na akty transgresji. Jej energia aktywizuje mobilny porządek tożsamości, prowokując do wyrażenia doświadczenia wewnętrznego przede wszystkim w sztuce, ale i w demonstracyjnych zachowaniach, wykroczeniach poza barierę wykluczenia, społeczne i obyczajowe schematy, konstrukty mentalne, polityczne ostracyzmy. Jak ujmował to Mieczysław Porębski, transgresja jest rodzajem konieczności egzystencjalnej, która tym bardziej staje się udziałem artysty: „istoty obdarzonej wyobraźnią nie można powstrzymać od tego, żeby rozsądnej granicy [codziennych swych - D.O.W.] możliwości ustawicznie nie łamała, nie gwałciła, nie przekraczała" (Porębski 1962: 52). Doświadcza jej zarazem obserwująca i komentująca publiczność, gdy w malarstwie i w spektakularnych zachowaniach otrzymuje wewnętrzną operację psychologiczną, informacyjną. Stanisław Rosiek tak komentuje powyższe założenia:

Ową wewnętrzną operację informacyjną [...] charakteryzuje znamienna niecodzienność przekazu, który mówi o tłumionych normalnie możliwościach, pragnieniach i aspiracjach człowieka w sposób nie tylko jawny, ale ostentacyjny, demonstrując aż do końca z całą rozrzutnością zasobów i energii groźny i oszałamiający zarazem mechanizm przekroczenia (Janion, Rosiek, red. 1984: 440).

Ten „groźny i oszałamiający mechanizm przekroczenia” uwyraźnia się przede wszystkim w wizerunkach Genki Genkova, ekstrawertycznego, skandali-

10 Cytat (i pozostałe oznaczane tym nazwiskiem) pochodzi z ekfrastycznego eseju Dimitra Boczeva pt. Khudozhnikŭt i kanarcheto (Artysta i kanarek), zamieszczonego w autorskiej książce Słowa sprzeciwu (wyd. Hermes, Sofia 2016). Boczev to ceniony (nie tylko w Bułgarii) pisarz, filozof, eseista, autor m.in. książek: Lądowanie pośrednie, Genesis II, Niebieskooki niewidomy, Homo emigranticus. Studiował filozofię na Uniwersytecie Sofijskim im. Klemensa Ochrydzkiego. Wielokrotnie aresztowany przez sв jako opozycjonista, dwukrotnie relegowany z uniwersytetu, w 1972 roku wyjechał nielegalnie z Bułgarii do Niemiec Zachodnich, gdzie otrzymał azyl polityczny. Był stałym współpracownikiem Deutsche Welle, później redaktorem programowym bułgarskiej edycji Radia Wolna Europa, odpowiadającym za program kulturalno-publicystyczny „Kontakty”. W 1976 roku został zaocznie skazany na 10 lat więzienia, który to wyrok uchylił Sąd Najwyższy w Sofii w 1992 roku. W artykule korzystam z cytowanego eseju na stronie internetowej czasopisma „Literaturen Vestnik”. 
zującego dysydenta. Na ich tle specyfika introwertycznego Nikifora, uchwycona w tekstowych „sur des images de l’artiste”, kieruje uwagę ku temu, co stanowiło transgresywne demonstracje wyobraźni i aspiracji, tłumione przez „wyrzutka”.

Ekfrastyczne reprezentacje, do których będę się odnosić, wyczulają w moim odbiorze na wartość i potrzebę transgresji rozsadzającej schematy. Te teksty są śladem i nośnikiem waloryzacji istotnych dla rozumianej kulturowo Europy Środkowej, doświadczanej także w jej powojennych przemianach. W samej zaś ekfrazie niejako genetycznie tkwi potencjał transgresywny. Czy w swoich realizacjach rozpatrywana intersemiotycznie, czy intertekstualnie, pozostaje „inter-”: w oscylacji pomiędzy znakami wizualnymi i werbalnymi. Przekracza granice kodów, formuł wypowiedzi jako rodzaj przekładu z jednego języka na inny, jako tłumaczenie, objaśnianie w innej postaci tekstowej czegoś niejasnego. Jej transgresywny potencjał uświadamia także fakt, że ekfraza niejednokrotnie „wkracza” w granice innego gatunku i, przekraczając je, komplementarnie się z nim łączy, dopełnia. Może wszak występować:

Jako osobny utwór albo fragment większego dzieła, w trzech rodzajach literackich i powiązanych $\mathrm{z}$ nimi gatunkach, również $\mathrm{w}$ gatunkach pogranicznych, jak esej, a także w krytyce sztuki (której zresztą niektóre przykłady można by ulokować w strefie gatunków pogranicznych, jako mające walory i naukowe, i artystyczne, i publicystyczne) (Słodczyk 2018: 368).

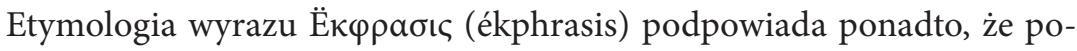

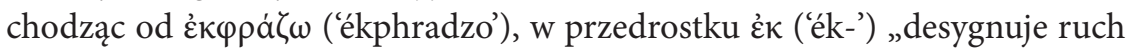
z wewnątrz na zewnątrz” (Popowski 2004: 33), ma niejako wpisaną ekspansywność. Przekracza granice: wewnętrznego świata obrazu, przekładając go na ekspresję werbalną, tak samo jak wewnętrznego świata artysty, gdy pamiętać, że w ekfrazie i ekfrastyczności zawiera się opis i wyjaśnianie idei obydwu. Tkwiący

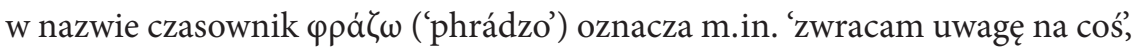
'wyjaśniam, 'poddaję myśl', 'rozważam, 'przypuszczam,' 'spostrzegam' (Dziadek 2018: 150). Sensy, które pozwalają się wyinterpretować z utworów uobecniających malarstwo oraz postacie Nikifora i Genkowa, poddają zaś pod rozwagę kilka analogii spostrzeżonych w lekturze.

O pierwszym z nich, co utrwalone w tekstach, mawiali Łemkowie i starzy kryniczanie: „sietniák”"11, rzadziej, z domieszką niepewności: „jurodiwy”,

11 Sietniok/sietniak (od siec - 'ścinać zboże sierpem') - prymityw, niewydarzony, niepełnosprawny człowiek, słaby, wątły. Także: dziecko, które pochodzi z jawnego grzechu, zdrady i jest tym napiętnowane. 
wszak nie w sensach nadawanych przez Dostojewskiego, a w myśl znaczeń niesionych staroruską etymologią ${ }^{12}$. Drugiego z nich nazywano powszechnie Genką-wariatem (Ruenov, dostęp 2020) ${ }^{13}$, w odbiorze sytuowano go zaś raczej w pobliżu artystów wyklętych („To tak, jakby Genkov ucieleśniał obraz artysty ubiegłego wieku, który za życia jest odrzucony i nieszczęśliwy, a po śmierci jego obrazy osiągają wysokie ceny” (Bakałov, dostęp 2020)). Tak też o nich pisano.

W przywoływanym już opowiadaniu o spotkaniu z Nikiforem Szczepański sugestywnie konstruuje środowiskowy wizerunek artysty, odpowiadający realiom:

[...] Dużo się pan z nim nie nagada. On nawet mówić nie umie. Coś tam bełkocze. Taki, co go dobrze zna, to może i zrozumie coś niecoś, ale sensu i tak w tym nie ma. To po matce, wie pan. Niemową była. Sietniaczka, tak tutaj mówią. Tułało się to po ludziach jako pomywaczka, jako służąca. Ktoś jej bachora zrobił. No i niedaleko pada jabłko od jabłoni. On też taki. Sietniak (Szczepański 1983: 62).

Pogardliwa charakterystyka Łemka, umieszczona w partii dialogicznej, a wyrażona w brutalizującej stylizacji kolokwialno-gwarowej przez drugoplanową bohaterkę (powołaną głównie dla zbudowania kolorytu lokalnego i naszkicowania uprzedzeń otoczenia), wyostrza jego ułomność i napiętnowanie.

12 Jurodiwyj (od staroruskiego urod') - „poroniony” człowiek, osoba głupia, bezrozumna, ale i święty głupiec, nienaturalny, zniekształcony, zdeformowany, obcy, tajemniczy, niezrozumiały. Podaję za indeksami dla słów yuRODIwy/ JURODYwYJ, UROD w akademickim słowniku wyjaśniającym języka ukraińskiego (Słownyk ukrainskoj mowy..., dostęp 2020), a także na podstawie największego słownika języka rosyjskiego, dziewiętnastowiecznego opracowania Władimira Iwanowicza Dahla, cieszącego się szczególnym uznaniem językoznawców (Dahl 1882). Znaczenia „jurodiwych”, w których kultura ludowa mieszała się z wpływami religijnymi, wiązały się także ze słowami św. Pawła: „[... staliśmy się dziwowiskiem światu i aniołom i ludziom. Myśmy głupi dla Chrystusa, wy zaś roztropni w Chrystusie; myśmy słabi, wy zaś mocni; wyście poważani, my zaś pogardzani. Aż do tej pory i łakniemy, i pragniemy, i jesteśmy nadzy, i bywamy policzkowani, i tułamy się, i trudzimy się, pracując własnymi rękami. Złorzeczą nam, a błogosławimy, prześladują nas, a znosimy; znieważają nas, a prosimy. Staliśmy się jakby plugastwem tego świata, śmieciem wszystkich, aż dotąd" (1 Kor 4,9-13) (Pismo Święte...1962: 1339).

13 Ruen Ruenow (historyk sztuki, dziennikarz, jeden z redaktorów czasopisma „Iskustwo/ Art in Bulgaria”) posługuje się tym „epitetem stałym” już w tytule swojego artykułu Genko Genkov-Ludiya... (Genko Genkov-wariat...) (Ruenov, dostęp 2020), datowanego pod tekstem "noemwri 2002". 
Stanowi kontrastowe tło dla empatycznych, analitycznych, choć niewolnych przecież od wstrząsu uobecnień Nikifora, zawartych w narracji odautorskiej i utwierdzających te same rysy postaci:

Wydął gardło, rozciągnął wargi, wycisnął z siebie jakiś bulgoczący dźwięk, który nie był ani odpowiedzią, ani pytaniem - może tylko sygnałem potwierdzającym, iż słyszy, że mówię do niego [...]. Nagle zawiesił pędzelek w powietrzu, skierował na mnie szkiełka swych okularów i z głębi krtani wykrztusił kilka zduszonych, niezrozumiałych sylab. Coś się wyklarowało w jego głowie, jakiś dialektyczny proces dobiegł końca. Komunikował mi jego wynik. Nie rozumiałem, powtórzył więc z naciskiem te same bełkotliwe dźwięki. [...] Wcale nie bredził. Tłumaczył mi, dlaczego nie może ze mną iść, a ja zachowywałem się tak, jakbym miał do czynienia $z$ wariatem. [...] Słowa czy raczej kikuty słów wyskakiwały wprost z rozdartego gardła pod ciśnieniem i głucho rezonowały w jamie ustnej, gdzie odrętwiały język nie mógł sobie poradzić $\mathrm{z}$ ich szlifowaniem. [...] Potok gardłowych dźwięków bluznął z jego krtani, pełen akcentów perswazji. Jak ludzie przyzwyczajeni do niekomunikatywności swego języka, powtarzał $\mathrm{z}$ naciskiem słowa, dziobiąc palcem w sepiową sylwetkę (Szczepański 1983: 66, 67, 71).

Reprezentacje literackie i paraliterackie Genki Genkova (głównie eseistyczne oraz zawarte w sfunkcjonalizowanych medialnie artykułach krytyków i historyków sztuki) powielają taki wizerunek:

Ochrypły głos, raczej warczenie. Ciągłe ruchy, kołysanie się w przód i w tył. Całość upaprana farbą. [...] Śmiech Genka, musi się go usłyszeć, jest jak ryk płonącego motocykla. Parzący. Kiedy wciśnie gaz, staje się to porażające (Ruenov, dostęp 2020) ${ }^{14}$.

14 Chcę w tym miejscu wyrazić serdeczne podziękowania prof. Kalinie Bahnevej (Uniwersytet Sofijski im. Klementa Ochrydzkiego) za pomoc w tłumaczeniu bułgarskich źródeł i zgromadzeniu materiałów. Przede wszystkim zaś za nieprzecenione rozmowy, które oświetlały mi konteksty bułgarskie, pozwalały weryfikować wątpliwości, konfrontować interpretacyjne intuicje. Pof. Kalina Bahneva, prócz tego, że mieszkała w Sofii w latach (głośnego w wielu znaczeniach) funkcjonowania tam Genki Genkova, znała malarza osobiście. Tym cenniejsze (i uwiarygodniające rozmaite teksty o malarzu) pozostawały Jej komentarze. 
Najgłośniejszy, nieogolony mężczyzna w pomiętym ubraniu zwrócił moją uwagę. Ktoś powiedział - to artysta, Genko-wariat. Kłócił się, a raczej spierał z innymi na tematy filozoficzne i polityczne. [...] W pewnym momencie swoim ochrypłym głosem zaśpiewał przebój Louisa Armstronga. Zrobił to całkiem dobrze. Poszedł się wysikać gdzieś na podwórku, a jeden z towarzystwa poskarżył się drugiemu - „Przekłuł mi ucho". Widywałem go latami tu i ówdzie w Sofii, na wystawach, w pubach (Bakałov, dostęp 2020).

Miejscem wspólnym wielu tekstowych kreacji są wątki wykluczenia obu malarzy, nie tylko ze względu na ich stygmatyzującą odmienność i, co nierzadkie, mimo rozpoznanego talentu. Na długo przed spektakularną karierą uznano w rodzimych krajach wartość ich dzieł, te zaś funkcjonowały jako paszporty Polski i Bułgarii do światowej sztuki ${ }^{15}$. Styl nieuczonego Nikifora-prymitywa odbierany był w kategoriach rewelatorskich: jak wcześniej kapistów, tak teraz następnych urzekały jego kolorystyczne gamy, idiomatycznie przetworzona architektura, operowanie przestrzenią, intuicyjny mariaż tradycji polskiej, łemkowskiej i ukra-

15 Po paryskiej wystawie prac Nikifora w 1959 roku (od 15 kwietnia), która - wbrew lękom Diny Vierny urządzającej tę ekspozycję w swojej prywatnej galerii - została przyjęta jako „la revélation de l’année”, w „L'Express” (z 23.04.1959) pisano: „Nareszcie prawdziwy naiwny. [...] Są to dziwne akwarele, o oszałamiającej niezręczności. Przypominają zarazem ikony, które Nikifor zna znakomicie, i dzieła Celnika Rousseau czy Viviana, których Nikifor nie zna zupełnie. [...] To prymityw xx stulecia - współczesny garncarzom azteckim sprzed dwóch tysięcy lat. Wystawa jego [...] jest być może, w tej światowej stolicy malarstwa rewelacją roku” (Rydzyńska i in. 2018: 90-91). O światowym powodzeniu malarstwa Genki Genkova zaświadczają dziś stałe ekspozycje jego prac w europejskich i amerykańskich muzeach (jak Muzeum Guggeheima w Nowym Jorku), niemniej przed transformacją ustrojową w Bułgarii Genkov nie znalazł mecenasów (jak stało się to w przypadku Nikifora) i karierę jego płócien potwierdzają głównie, poza wystawami sofijskimi, entuzjastyczne ich zakupy przez zachodnioeuropejskich, amerykańskich, azjatyckich dyplomatów i koneserów. Obrazuje te okoliczności np. taki komentarz, odnotowany już w okresie posttotalitarnym: „Azjatycki dyplomata pracujący w Sofii zadał naiwnie prowokacyjne pytanie: kto jest lepszym bułgarskim malarzem - Svetlin Rusev czy Genko Genkov? Genka pierwszeństwo było oczywiste dla zgromadzonych wokół znawców, co wyrazili jednoznacznie i jednomyślnie. [...] Francuscy dyplomaci i koneserzy przyjeżdżali do Sofii specjalnie po to, by zakupić jego obrazy. Kolejny rok z rzędu Genko jest absolutnym hitem na rynku, absolutnym rekordem sprzedaży. [...] Genko nadal sam sprzedaje swoje płótna we wszystkich dostępnych mu miejscach, nawet na ulicy. [...] Od lat jest najczęściej wystawianym i kupowanym bułgarskim artystą" (Genko Genkov e rekord'or... 2002). 
ińskiej. Malarstwo Genkova (radykalnie eksperymentującego z pigmentami, z tworzywami, którymi pokrywał płótna, z „rzeźbieniem” ich powierzchni), zawierające komponenty postimpresjonizmu i fowizmu, pociągało brawurowymi zestawieniami barw, kompozycjami, w których trudno tolerujące się kolory stwarzały równie trudny do zwerbalizowania efekt. Genko sam najadekwatniej określił te eksperymenty: „Grzebię w kolorach jak motyką” (cyt. za: Ruenov, dostęp 2020). W istocie, wystarczy obejrzeć choć kilkanaście jego obrazów, by docenić metaforyczny sens tytułu poświęconej mu monografii: Bunt na tsvetovete (Bunt w kolorach) (Jankov 2001). Czerwień kadmowa i purpura komunikują się na jego obrazach z fioletem, żółcią i błękitem kobaltowym, oranżami, zieleniami w tak bliskim sąsiedztwie, że odczuwana harmonia tym bardziej zaskakuje.

Skupowani za bezcen, Nikifor i Genko egzystowali przez dekady, dzień po dniu w swoich przestrzeniach: krynickiego deptaka i sofijskich ulic tak jawnie, że stanowili część ich krajobrazu, kolorytu. Jako że marny był to wtedy koloryt i życia, i dominujących w tej części Europy Środkowej nurtów sztuki, tym większymi okazywali się fenomenami dla literatów, artystów, kolekcjonerów świadomych ich potencjału lub go przeczuwających. Ich obrazy stawały się by użyć sugestywnej metafory Szczepańskiego - „oknem”, „jednym z okien, przebijających ściany mojego świata” (Szczepański 1983: 61). Jak odmiennie natomiast przebiegały transakcje prowadzące do pozyskania owego „okna”, co niemało powiada tak o przeciwności usposobień Łemka i Bułgara utrwalonych w tekstowych kreacjach, jak o uświadomionej przez nich godności swojej niepospolitej sztuki, pospolicie zbywanej na co dzień w ulicznym obrocie, ilustrują narracje utrzymane w innych konwencjach, niemniej równie poglądowe:

Wytargowanie „Biskupa” nie przyszło mi łatwo. Wprawdzie Nikifor ochoczo wybebeszył zawartość drewnianej skrzynki na stół, ale kiedy przystąpiłem do wybierania, od razu zaczęły się trudności. Zwłaszcza świętych wyrywał mi z rąk, a potem jeszcze grzebał w kupce odłożonych na bok obrazków, jeszcze mu tego i owego było żal. Proponował zamianę lub po prostu zabierał rzecz raz już daną, mrucząc z irytacją. [...] Nasze spory i kompromisy zdawały się rozgrzewać Nikifora, rozbudzać w nim instynkt gry. Dostrzegłem w jego oczach przebiegłe błyski, a raz i drugi przyłapałem go na wyraźnie złośliwym uśmieszku, nadającym jego pofałdowanej gębusi wyraz zaskakującej inteligencji. Coś knuł. Wreszcie dobiliśmy targu (Szczepański 1983: 74).

Angielski ambasador, wybrawszy się na spacer wśród przyrody, zatrzymuje się przy Genku, wita, spogląda na płótno, w niewielkim stopniu 
przypominające krajobraz przed nimi, i przez chwilę przypatruje się pod wrażeniem. Wręcza wizytówkę, zaprasza Genkę, by kiedyś odwiedził go ze swoimi obrazami w ambasadzie. [...] Któregoś deszczowego dnia do ambasady angielskiej dobija się zmięty, nieogolony mężczyzna z dwoma płótnami w rękach. Funkcjonariusze otwierają mu i pytają, kim jest, czego szuka. Genko wręcza wizytówkę ambasadora i powiada, że ma z nim spotkanie. Zdumieni biegną zaraportować. Ambasador był akurat wolny, przyjął go. Genko wszedł do okazałego biura w swoich zabłoconych butach i umieścił oba obrazy w końcu pokoju. Ambasador zaproponował mu whisky, cygaro i starał się nawiązać rozmowę. Po chwili ostrożnie zapytał - Panie Genko, ile mam zapłacić za pańskie obrazy? Genko wskazał na pejzaże - za ten 2000, za tamten 3000 dolarów. Jak na bułgarskiego artystę w tamtym czasie, to były potężne kwoty, nawet ambasador ocenił ich wysokość. Próbował powiedzieć coś w tym sensie, że to i tak niewiele. Genko z pogardą sączył whisky, zaciągnął się cygarem i powiedział: „Dlatego my, Bułgarzy, potrafimy robić gesty”, odwrócił się od niego i wyszedł, pozostawiając obrazy (Bakałov, dostęp 2020).

Odmienni osobowościowo, krańcowo odlegli w malarstwie (jak tylko potrafią się różnić papierowe akwarele naiwnego prymitywisty, kreującego nostalgiczne nastroje w gamach złamanych zieleni, brązów, szarości, żółcieni, błękitów i fioletów, obrazki z ogromem detali oddzielanych wyrazistymi konturami od rozmachu awangardowych płócien Genkova porażających „paroksyzmem chromatycznym” (Jankov 2001: 31) i reliefem wydrapywanych nożem farb), wywoływali swoją sztuką podobne wrażenia. Wobec uderzającej odrębności technik i charakteru obrazowania Nikifora i Genkova uwyraźniają się analogie w ekfrastycznych deskrypcjach autorów opisujących spotkanie $\mathrm{z}$ fenomenem całościowego, malarskiego przetworzenia tego, co przez malarzy „zobaczone”, w odbicie idiomatycznego, a zarazem uniwersalnego porządku świata. W zasadzie adekwatniejsze jest w przypadku większości literackich i paraliterackich wykładni malarstwa obu artystów mówienie o hypotypiczności ${ }^{16}$ (Dziadek 2004),

16 Rozróżnienie, rozumienie ekfrazy i hypotypozy przyjmuję za Dziadkiem: „Ekfraza $\mathrm{w}$ ujęciu retorycznym wiązana jest często z inną figurą makrostrukturalną - hypotypozą, czasem do tego stopnia, że przez niektórych badaczy figury te są niesłusznie utożsamiane. Niesłusznie, ponieważ te dwie kategorie opisu różnią się w sposób zasadniczy [...]. Opis w hypotypozie - w przeciwieństwie do opisu w ekfrazie - nie odnosi się do konkretnego dzieła sztuki, ale raczej pośrednio przywołuje jakiś obraz" (Dziadek 2004: 76-77, 82, 
dominuje bowiem przewaga artykulacji odnoszących się do składników ich stylu, specyfiki tematycznej czy nastrojowej, nie zaś do konkretnych dzieł.

Komentujący obrazy Genki-wariata Ruen Ruenov określa ich efekt „porządkiem malarskiej materii tak wielowarstwowej, jak kompletne duchowe środowisko" (Ruenov, dostęp 2020). Monografista Nikifora nazwie kompozycje „sposobem jego filozofii” (Banach 1959: 85), co spotyka się z presupozycjami „filozoficzności” wyczytywanej z płócien Bułgara. Eseistyczne narracje, poetyckie monologi, krytyczne komentarze uwypuklają płynące stąd doznanie „momentu epifanicznego”, a może Heffernanowskiego „zalążka narracyjnego impulsu" "17 (Heffernan 1991: 307) czy Lessingowskiej „płodnej (niem. fruchtbar) chwili”, „owocnego momentu” (Lessing 1962: 16), co skutkowało ich własną twórczością. Niech koincydencje w wyrażaniu odbioru przedstawień Nikifora i Genkova zilustruje kilka cytatów polskich i bułgarskich. Celowo są one tak obszerne, by wyraźnie wybrzmiały analogie:

Ze sztuką tą (Nikifora) zetknęliśmy się ja i moi przyjaciele przed paru laty w Paryżu, zetknięcie było olśniewające [...]. Te małe obrazki są proste jak natura, jedyność ich polega wyłącznie na tym, że najzupełniej szczerze zobaczono rzeczywistość innymi niż wszyscy oczyma. [...] Dziwność ich spowodowana jest abstrakcyjnością jego malarskiego podejścia, ale abstrakcyjność ta nie ma nic wspólnego z nierealnością, jego świat jest zawsze najzupełniej konkretny, jest tylko konieczne oderwanie się od przedmiotu po to, by przedmiot odtworzyć poprzez malarstwo (Wolf 1938: 24-25).

Patrzę - na płótna Genko Genkowa, a myślę o Romainie Rollandzie, o jego powieści Jan Krzysztof. „Zadaniem artysty jest właśnie to - stworzyć słońce, kiedy go nie ma”. Tak, tylko tak być powinno. Kiedy ono jest, ja też mogę [je stworzyć - D.O.W.]. Nawet i Szyszkin może, kiedy ono jest. A kiedy go nie ma, ja nie mogę - tym mniej może Szyszkin.

wyróż. A.D.). Dziadek wskazuje, że w przypadku hypotypozy intencja autora wiąże się $\mathrm{z}$ unaocznieniem czytelnikowi nie tyle konkretnego malowidła, ile całej grupy, klasy płócien o podobnym obrazowaniu, tematyce, stylu, idei. Tak też najczęściej (z niewielkimi wyjątkami) przedstawia się sytuacja w tekstach odnoszących się do malarstwa Nikifora i Genki Genkova.

17 "[Ekphrasis - D.O.W.] typically represents the arrested moment of graphic art not by re-creating its fixity in words, but rather by releasing its embryonically narrative impulse" (Heffernan 1991: 307). 
Tylko Genko może [je stworzyć - D.O.W.], gdy słońca nie ma. Widać wiedział, wyraźnie czuł, że mimo swego geniuszu twórca, który postrzegał artystów jako lekarzy do upiększania, mylił twórczość z kosmetyką - jeśli ktoś jest artystą, maluje nie zewnętrzność, a to co wewnątrz. [Bo - D.O.W.] wierność to nie dokładność formy - w sztuce wierność podąża za krzywą doświadczenia. Dlatego drzewa Genko Genkova nie są drzewami - a jego domy nie są jak domy (Boczev, dostęp 2020).

Nigdy nie przeżyłem większych emocji od tych, które wzbudziły we mnie jego [Nikifora - D.O.W.] obrazy oglądane na żywo. [...] Wszystko, co malował, jest zobAczone. A potem to zobaczone tasowało się w jego pamięci, wyobraźni, swobodnie. On wyzwalał się wspaniale z przymusu rzeczywistości i kreował obraz, świat, własną ich strukturę. Opowiadał siebie, malował swój kosmos (Dwurnik 2005: 92).

Właśnie dlatego obrazy Genko Genkova stały się mi nagle bliskie i drogie - ponieważ nagle do mnie przemówiły. To była miłość od pierwszego wejrzenia. A jeszcze sto lat temu Bernard Shaw szepnął mi, że zna pewne lekarstwo na miłość od pierwszego wejrzenia: drugie spojrzenie. Ja też spróbowałem: w środku tego pomylonego tekstu wstałem i znów pobiegłem do sali wystaw [...]; po drugim spojrzeniu jeszcze bardziej pokochałem jego obrazy. Więc to nie była tylko miłość od pierwszego wejrzenia - to była miłość także przy drugim spojrzeniu. I trwa. Dziś jest już za późno, ale jutro spróbuję i trzeciego spojrzenia. Chociaż mam przeczucie, chociaż już wiem, że oczyma nie przestanę go kochać, nie „odkocham się” i sercem. Nawet jeśli nie całkiem to rozumiem (Boczev, dostęp 2020).

W malarstwie Nikifora spotyka się to, co lokalne i globalne, przemijające i wieczne, zmysłowe i ponad-zmysłowe. Raczej nie idee i ich konkretyzacje - Nikifor przejawia raczej tendencję do syntetyzowania i uniwersalizacji doświadczeń. Przetwarza je w taki sposób, że wpisują się w wertykalny porządek świata - w jego metafizyczną perspektywę [...], gdzie rzeczywistość rozgrywa się jednocześnie w niebie i na ziemi, na górze i na dole, a światy te są ze sobą w jakiś tajemny sposób styczne (Szerszeń, dostęp 2020).

Dwa światy - ziemski i pozaziemski - i jeden pędzel, który linia po linii rysuje między nimi most, linia po linii przełamuje ich niezgodność, 
czyni je kompatybilnymi i jednorodnymi: dopóki ich nie dopasuje, łącząc niepodzielnie w jeden wszechświat. Nie wiem, jak doszło do tej unii magnetycznej - prawdopodobnie artysta też nie wie. [...] Nie wiem dlaczego, nie wiem, skąd i którędy nadchodzi ten powiew wieczności, to czucie wszechświata, ten zapach niezniszczalności, skąd się bierze i jak się to dzieje. Wiem tylko, że jest dość jednoznaczny, zmysłowy, fizycznie wyczuwalny (Boczev, dostęp 2020).

Wobec krańcowej odmienności stylów Łemka i Bułgara powyższe zestawienie cytatów, w których podobieństwo komentarzy do ich obrazów jest wyraźne, może wybrzmieć jak coincidentia oppositorum. Naturalnie, nie musi dziwić taka zbieżność przeciwieństw przy ekspresywności przywołanych artykulacji, ich zorientowaniu na syntetyczną (i motywującą poruszenie) interpretację fenomenów, wobec znaczącego uogólnienia „ducha” artefaktów i uwag o potencjale twórców. Podobne zbieżności ujawniają się w tekstach z „hypotypicznym zaszczepieniem”, które silniej niż ich sztuką rezonują osobowościami Nikifora lub Genkova. Mimo istotnych kontrastów (współmiernie do przeciwnych usposobień i indywidualnych kolei życia artystów), w zsubiektywizowanych, pisarskich kreacjach są miejsca wspólne.

Nikifor uobecniany jest konsekwentnie jako milczący analfabeta z poważną wadą słuchu i wymowy, o słabym wzroku, sprawiający wrażenie pokornego, niebywale systematyczny w rytmie codziennej pracy (malował zazwyczaj od 5 do 8 obrazów), uchodzący długo za pomylonego niemotę-wyrzutka ${ }^{18}$.

18 Takie (i synonimiczne) określenia funkcjonują w rysach biograficznych Nikifora, we wspomnieniach ludzi z jego otoczenia czy odtwarzających zapamiętany z Krynicy widok malarza przy pracy. W większości portretów Nikifora zawartych w tekstach o bardzo różnej kwalifikacji formalnej (literackich, paraliterackich, krytycznych, prasowych etc.) eksponowany jest traumatyczny wymiar jego biografii. Legendy mieszają się z faktami, co dziś - w dobie cyfryzacji, multimedialności i tym łatwiejszego powielania informacji nie zawsze udokumentowanych - wpływa zapewne na utrwalanie się w jego wizerunku szczególnie drastycznych wątków, epizodów, doświadczeń. Niemal od narodzin był napiętnowany społecznie jako nieślubne dziecko Łemkini, Jewdokii Drowniak (córki Hryhoria i Tatiany z domu Krynickiej ze wsi Poworoznyk), zapamiętanej jako głuchoniema posługaczka w krynickim pensjonacie „Trzy róże”, dorabiająca roznoszeniem wody zdrojowej do innych willi. Powtarzają się zapiski, że wraz z matką żyli w izolacji, ta zaś, idąc do pracy, zawiniątko z chłopcem zostawiała pod mostem, a kiedy był starszy, wstydziła się go i odganiała od siebie. Na temat ojca Nikifora wiele jest legend łącznie z tą, iż miałby nim być Aleksander Gierymski, uwiedziony urodą Jedwokii, gdy koił nerwy w kurorcie. Po ojcu miał więc Nikifor odziedziczyć talent, po matce wadę słuchu 
Żebrząc swoją sztuką na krynickim deptaku, posługiwał się - napisanymi zawsze cudzą ręką - listami proszalnymi ${ }^{19}$ o wsparcie „czem kto może”, „aby się tylko utrzymać na tym Bożym świecie” (Karski, dostęp 2020). Do popaździernikowej odwilży bez stałego meldunku (władze nowosądeckie wydały zakaz meldowania Łemków), potem zakwaterowany w izbie drewnianego budynku, niezmiennie na wiele godzin „wychodził do pracy”. Stanowił niemal część krynickiego pejzażu, dla większości wtopiony w powszedniość, dla przyjezdnych atrakcję, dla innych cel pielgrzymki. Takim też utrwalili go Jan Józef Szczepański, Zbigniew Herbert, Konstanty Ildefons Gałczyński, Jerzy Harasymowicz, Janusz Szuber, by tymczasem ograniczyć się do wskazania reprezentatywnych odniesieńe ${ }^{\circ}$ z porządku literackiego. Szczepański pisze, znów uobecniając Nikifora w konfrontacji dwóch

i wymowy, po obojgu: traumę. Wcześnie osierocony, tułał się pośród przygarniających go ludzi, żebrał. Tu znów sporo jest opowieści, także ta, która sugeruje porwanie młodego Nikifora przez dwóch malarzy (niektóre źródła wskazują na architekta Tadeusza Stryjeńskiego i jego brata Karola). Po akcji „Wisła” trzykrotnie wywożono Nikifora pod Szczecin jako Łemka, szpiega, żebraka. Dotychczasowe jego napiętnowanie, głównie społeczne, wzmogło się napiętnowaniem politycznym, gdy ten niezmiennie wracał pieszo do Krynicy i zasiadał do pracy pod pomnikiem Mickiewicza. Ostatecznie zaprzestano deportacji Nikifora, za którym ujął się Juliusz Zawadowski, ówczesny naczelny lekarz uzdrowiska i zarazem burmistrz Krynicy. 31 sierpnia 1948 roku Zarząd Miejski Krynicy wystawił legitymizujące zaświadczenie: „Obywatel Nikifor zwany «Matejko» jest synem głuchoniemej o niewiadomym pochodzeniu. Urodzonym w Krynicy-wsi powiat Nowy Sącz. Kawaler. Trudni się ulicznym malarstwem”. Rzecz jasna, pozbawiono go w „formalnym dokumencie” niewygodnego, łemkowskiego pochodzenia. Po raz kolejny, w bardziej spektakularnym wymiarze, nastąpiło to oficjalnie przy wydawaniu sześćdziesięciosiedmioletniemu Nikiforowi pierwszego dowodu osobistego (zob. przypis 1), który przyjął - jak domniemują ludzie z jego otoczenia - obawiając się represji. Zarówno w akcie urodzenia, jak w dowodzie i paszporcie, postanowieniem Sądu Rejonowego w Muszynie z 18 października 1962 zmieniono mu tożsamość, imiona rodziców, datę urodzenia (Nikifor Krynicki, ur. 1 stycznia 1895, syn Jana i Kseni). Dopiero w 2003 roku na wniosek Zjednoczenia Łemków ten sam sąd uchylił wcześniejsze postanowienie i pośmiertnie przywrócono Nikiforowi tożsamość (Epifaniusz Drowniak, ur. 21 maja 1895, syn Jewdokii Drowniak).

19 O listach proszalnych Nikifora, których było kilkadziesiąt, jako specyficznym i charakterystycznym zarazem elemencie jego twórczości wspomina się często. Pisze o nich m.in. Bogdan Karski, autor artykułów o fałszerstwach prac Nikifora, opatrując tekst o ilustrowanych przez malarza listach i innych „nikiforianach” galerią zdjęć. Na stronach internetowych tego autora widnieją kopie ponad dwudziestu dokumentów, o których mowa (Karski, dostęp 2020). Ich fragmenty cytuję za Karskim.

20 Z. Herbert: Wywiad z Nikiforem, Nikifor (felieton), Nikifor (wiersz), także wzmianki na jego temat, w kontekście Łemków, w rozmowie z Jackiem Trznadlem w Hańbie domo- 
punktów widzenia - miejscowej bohaterki (wprowadzenie mowy niezależnej „uwiarygodnia" tu obraz) oraz odmiennie wartościujących impresji narratora:

Na pewno siedzi tam, gdzie zawsze, naprzeciwko starych łazienek. [...] A co mu deszcz? On nie dba o to. Zresztą gdzie ma siedzieć? - dodała W tej ciemnej szopie, gdzie mieszka? To dziad. Żebrak. [...] Siedział tam, gdzie mi wskazano, na murku pod „Soplicowem”, naprzeciwko starych zdrojowych łazienek. Dostrzegłem go od razu w pustej uliczce tak bardzo samotnego, jakby nie należał do tego świata. [...] Mała, ciemna kukiełka pochylona cierpliwie nad spoczywającą na kolanach skrzynką. [...] Nikifor nie podnosił głowy znad roboty. Odrywał wzrok od leżącego na wieku skrzynki kawałka tektury tylko wówczas, gdy przyszło mu zanurzyć pędzelek w szklance z brudną wodą i odszukać odpowiedni guziczek anilinowej farby na dziecinnej kartonowej paletce, które to przybory umieścił obok siebie, na murku. Świat zewnętrzny zdawał się nie istnieć dla niego (Szczepański 1983: 64-65).

Jak bardzo realistyczny jest ów literacki portret, pokazuje choćby zderzenie go ze wspomnieniem lekarza permanentnie widującego Nikifora w Krynicy, potem leczącego w szpitalu $\mathrm{z}$ beznadziejnie zaawansowanej gruźlicy:

Malował szkolnymi farbkami, rzadziej kredkami woskowymi, używając, jako papieru, okładek ze szkolnych zeszytów, pudełek po papierosach, kawałków tektury. Farbki rozcieńczał własną śliną, co budziło odruch wstrętu u obserwatora, a u miejscowych, którzy dodatkowo wiedzieli, że choruje na gruźlicę, obawę o zawleczenie choroby do swoich domów. Z tego powodu jego obrazki były niszczone (najczęściej palone) i tylko nieświadomi choroby mistrza i jego techniki malarskiej kuracjusze i turyści, powodowani pięknymi kolorami i litością nad nędzą artysty, brali obrazki za symboliczną cenę 50 groszy, czasem 1 złotego. [...] Było charakterystyczne, że podczas pracy zupełnie nie zwracał uwagi na otaczający go tłumek gapiów. Obawiał się tylko dzieci, które go zaczepiały, poszturchiwały i przeszkadzały (Niemiec, dostęp 2020).

Na ulicach Sofii - maluje Genkov. Sprzedaje za bezcen, nim zdążą doschnąć, swoje płótna (osiągające z czasem, jak prace Nikifora, znaczące notowania).

wej; K.I. Gałczyński: Dramat w tunelu; J. Harasymowicz: Drowniak Netyfor, Tryptyk Nikiforowski; T. Różewicz: Zwierciadło, J. Szuber: Kto?. 
Wpadając z nimi do tramwajów, wprawia w konsternację zachowaniami pełnymi sprzeczności i najróżniejszymi w tonacji, głębi, tematach wywodami. Nie ma pewności: wariat, margines czy filozofujący geniusz? Kompulsywny, gadający, „siniaczący słowa” (Bakałov, dostęp 2020), wręcz krzyczący:

Ważne jest, aby powiedzieć to coś. Całkowita komunikacja, wszędzie, z każdym. [...] Nawet jeśli nie wiedzieli, że jest artystą, wielu widziało jakiegoś „rogatego” podobnego do chmury, który warczy i coś oznajmia. 1961 czy 1986, to nie ma znaczenia. Zima. Pada śnieg. Genko na Rakowskim [na ul. Rakovskiego - D.O.W.] w płaszczu. [...] Nieznośnie ogłuszający. Ochrypły. Brutalny krzyk. Tarzan ożył na Rakowskim. Czy to prawda czy nie? Nikt nie ośmiela się uwierzyć, że To usłyszał. Przestrzeń się wygięła. Przechodnie szybko przechodzą na drugi chodnik. [...] Sam artysta naprawdę wygląda jak stary Tarzan, który nie stracił energii. Albo Godzilla, albo cherubin, albo św. Efraim z Boyany, sądząc po fryzurze i wyglądzie (Ruenov, dostęp 2020).

Genko chodził po autobusach i tramwajach ze swoimi jeszcze mokrymi płótnami i oferował je za bezcen. [...] Kobieta woła - gada im to wszędzie. „Gangsterzy w Ameryce czyszczą pasożyty, w naszym kraju wręcz przeciwnie, pasożyty są zawsze u władzy - komuniści czy kapitaliści, bez różnicy. Utrzymują się, wspierają. [...] Pasożyty próbują zabić artystę, okraść jego wdowę, jeśli się nie zgodzi, zabić jej dzieci. To jest ten świat, wojna o wysysanie ludzkiej krwi”. Rozmawia w tramwaju. A gliny nas zabierają. "Rozmawiam z kimś i oni idą z nami. Czekaj, nie jestem przestępcą. TYLKO mówię. Chcieli, żebyś lizał ich tyłek i krzyczał, że nie ma większego raju niż ich”. Nóż drapie. Wydaje się wesoły. Maluje nożem. Dokładniej, wydrapuje nim płótno, uprzednio zanurzywszy ostrze w jakimś słoiku. Skrobanie jest ciche, ale słychać je wyraziście, podczas gdy Genko od czasu do czasu mówi: fajnie, fajnie. Jedną ręką trzyma płótno za wewnętrzną ramę, a drugą skrobie. Płótno się wygina (Bakałov, dostęp 2020).

Tak konstruowane sylwetki Nikifora i Genkova, multiplikowane w zasadniczych rysach, wskazują na oczywiste, osobowościowe przeciwieństwa artystów. Są one jawne i w utworach z wysokiego rejestru poetyckiego, prozatorskiego, eseistycznego (Herberta, Boczeva, Szczepańskiego), i w paraliterackich artykułach krytycznych, wspomnieniowych, felietonowych (tych jest wiele). Niezależnie od sfunkcjonalizowania oraz odniesień artykulacji do każdego z malarzy, 
niezmiennie powtarzają się komplementarne ujęcia sztuki i manifestujących się ich osobniczych rysów.

Jedność przeciwieństw zaczyna się ujawniać na poziomie pęknięć w tekstowych kreacjach postaci. Autorzy sygnalizują niespójności, które prowokują do pytań o uświadamianą bądź instynktowną autokreację, o aranżowanie własnego portretu, projektowanie pożądanego odbioru dostosowywanego do opresywnych okoliczności życia, traumatycznych biografii, imperatywu tworzenia. Bywa, że wprost stawiane są pytania (z reguły retoryczne) wobec pełnego dysonansów demonstrowania się artystów, jak to cytowane, dotyczące Genkova: „Szalony, alkoholik, cyklofrenik czy dobry aktor, który potrafi razem odgrywać te marginalne role?”. Uobecnienia Nikifora także zawierają sporo wskazań ambiwalencji towarzyszących autorom przy scalaniu tekstowych kreacji. Kreacje te są wypadkową interpretacji malarstwa krynickiego Matejki (i stamtąd wywiedzionych projekcji jego osobowości) oraz bądź to własnych obserwacji piszących (gdy go widywali, znali), bądź to zasłyszanych opowieści („legendotwórczy potencjał" Nikifora był oczywisty). Monografiści Nikifora wielokrotnie wskazują na niewspółmierność ujawniających się jego rysów. Aleksander Jackowski (Jackowski 2010), selektywnie objaśniając zasady estetyczne obrazów Łemka, reguły jego stylu, przestrzenny układ postaci, symbolikę itd., projektuje przeważnie tę interpretację na samą postać artysty. Zarazem jednak ukazuje go jako człowieka zaskakującego odsłanianymi cechami, strategiami, które destabilizują utwierdzony ( $\mathrm{z}$ udziałem świadomej autokreacji?) wizerunek. Taki, jaki zbudował w swoim opowiadaniu Szczepański, odbijając własne wrażenie (konfrontowane $\mathrm{z}$ upowszechnioną recepcją) w ekspresywnych deminutiwach. Stanowią one ślad empatii i poruszenia kruchością oraz nędzą Nikifora, zderzonych w tekście z wielkością jego talentu. Rangi tego talentu Szczepański dowodził z ekfrastyczną nadzieją ${ }^{21}$ (Mitchell 1994) w rozpoczynającym Biskupa jadącego przez morze przedstawieniu obrazu. Artefakt stał się poniekąd narzędziem uruchamiającym komponenty racjonalne w portretowaniu Łemka - uobecniając analitycznie jego sztukę, Szczepański wykazywał w ekfrastycznej wykładni jej wysoką wartość. W partiach opisujących Nikifora-człowieka aktywizowane

21 Ekphrastic hope - charakteryzuje ją poczucie, że dzięki wyobraźni ekfraza pozwala nam zobaczyć to, co opisuje. Termin Williama Johna Thomasa Mitchella, którym określa on jeden z etapów fascynacji ekfrazą (obok ekphrastic indifference - ekfrastycznej obojętności i ekphrastic fear - ekfrastycznego strachu), objaśniany m.in. przez Bartosza Swobodę (2011) i Grzegorza Jankowicza (2010). Słodczyk, przywołując termin Mitchella, sugeruje, że owe trzy fazy w fascynacji ekfrazą „można potraktować jako trzy różne podejścia do zagadnienia ekfrazy" (Słodczyk 2018: 356). 
są zaś czynniki emocjonalne, taką też konkretyzację projektuje Szczepański u wirtualnego odbiorcy, wywołując ekspresywną artykulacją wzruszenie. Zdystansowana, racjonalna refleksja zostaje uchylona szeregiem epitetów i metafor apelujących do współczucia, rozczulenia: „postać bardzo licha”, „mała, ciemna kukiełka pochylona cierpliwie nad spoczywającą na kolanach skrzynką”, „okulary w drucianej oprawce, $\mathrm{z}$ jednym szkiełkiem oślepionym wielopromienistą gwiazdką pęknięcia”, „ujął [...] laseczkę”, „maleńki jak dziecko”, „uśmiechnął się uprzejmie i z roztargnieniem”, „mała gębusia poskładana w poprzeczne fałdy”, zatopiony w „Nikiforowym świecie” (Szczepański 1983: 64, 65, 68, 70).

Wizerunek pokornego, wykluczanego Łemka, niemal „świętego malarza świętych", jest dominujący. Odnosi się zresztą do niego po wielu latach (w rozmowie z Łukaszem Maciejewskim) Krzysztof Krauze, twórca filmu²2 Mój Nikifor: „[...] uczył się malarstwa w cerkwi, z ikon. Święci na ikonach byli mu bliscy, bo milczący jak on" (Maciejewski 2004: 26). Wizerunkowi temu, równolegle ze stabilizowaniem go przez kolejnych autorów, stawiane są zarazem pytania, niekoniecznie li tylko w horyzoncie naturalnych, wpisanych w ludzką konstrukcję „spontanicznych” autokreacji. Jackowski, podobnie jak dobrze znająca malarza Jadwiga Jarnuszkiewiczowa, czasami odnoszą się sceptycznie do jednostronnych utrwaleń Nikifora. Czynią to w emocjonalnym tonie, tu jakby stanowiącym przeciwwagę dla równie emocjonalnych, a bywa, że nazbyt wygładzonych, reprezentacji, niebiorących pod uwagę elementu strategii, gry, pragmatycznego „korzystania” przez Łemka z (uschematyzowanej z latami) jego recepcji:

Biedny Nikifor! Tyle w życiu wycierpiał, a teraz to sobie kompensuje w obrazach. Gotowi jesteśmy go rozgrzeszyć, jeszcze pogłaskać — taki biedny i taki naiwny! A on jest po prostu okrutny. Rozrzewnia nas, ponieważ niczego nie może, nie jest i nie może być groźny. Ale czy przez to okrucieństwo jego staje się mniejsze? [...] Nikifora wcale nie krępuje żebranie. To my jesteśmy zakłopotani. Idąc do pracy (na swoje miejsce

22 Ta głośna fabuła z 2004 roku, obejmująca „trzy miesiące w 1960 roku (początek przyjaźni Nikifora i Włosińskiego), dwa dni w 1967 (wielka retrospektywna wystawa Nikifora w Zachęcie), jeden dzień w 1968 roku - śmierć Nikifora” (Maciejewski 2004: 27), zamierzona przez reżysera jako trzecie odkrycie Nikifora, dla kolejnego już pokolenia (po pierwszym odkryciu, w okresie dwudziestolecia, przez kapistów i drugim, po wojnie, przez małżeństwo Elli i Andrzeja Banachów), to zarazem drugi film o Nikiforze. Pierwszym był barwny, sześciominutowy dokument Jana Łomnickiego Mistrz Nikifor (1956). Także o Genkovie powstał w 1994 roku film: Genko, dziewięćdziesięciominutowy, eseizowany dokument w reżyserii Borjany Punczevej. 
przy murku) obchodzi z kapeluszem w ręku kuracjuszy siedzących na ławkach przy Pijalni. Dadzą dobrze, nie dadzą - trudno. Ale dlaczego miałby nie wykorzystać sposobności zarobienia? Jest niedziela. Siedzimy z Jadwigą na ławce. Zbliża się Nikifor. Nie zauważa nas, podchodzi, bełkocąc swoją prośbę, Nikifor! wołam. Poznał, zakłopotany uśmiech, chowa kapelusz. Odchodzi, wyraźnie speszony. Ale już po chwili widzę, że znów krąży wśród ludzi z kapeluszem w dłoni (Jackowski, Jarnuszkiewiczowa 1985: 232, 235).

To prawda, że tych możnych i silnych szanował a poniżonych nic. Ale czy nimi gardził? Nie sądzę. Jeśli rechotał z radości oglądając zdjęcia z prześladowania Żydów, czy donosił na gosposię to myślę, że była to sprawa raczej kompensacji niż pogardy (Jackowski, Jarnuszkiewiczowa 1985: 237).

Także w łemkowskich wspomnieniach, których pojawiło się wiele w związku z działaniami wokół przywrócenia Epifaniuszowi Drowniakowi tożsamości, są zapisy wskazujące na jego autokreacje. Bywają one rozczulająco zabawne, infantylne, niemniej są dodatkową przesłanką do refleksji o strategiach niekoniecznie nieuświadamianych przez Nikifora, postrzeganego powszechnie jako naiwny (nie tylko w malarstwie) i utalentowany, ale niesprawny umysłowo $^{23}$. Zapisy dotyczą różnych aspektów budowania własnego wizerunku, też tych związanych z wyglądem: „Jak zaczął zarabiać, ładnie się ubierał. Przy

23 Jackowski odnotowuje: „Kiedy był u mnie w Warszawie, postanowiłem pokazać go lekarzom. Badania przeprowadzano w Instytucie Higieny Psychicznej przy ul. Chełmskiej. [...] Badaniami kierował prof. Zajączkowski. Ja występowałem w charakterze tłumacza. [...] Sytuacja była niezręczna. Psychologowie stosowali standaryzowane testy, on zaś miał już 60 lat i był osobowością ukształtowaną, wybiórczo wybitnie utalentowaną. Niby to rozumieli, ale nie potrafili dostosować testów i pytań do osobowości Nikifora. Stosowano m.in. serię testów Wechslera-Bollevue. [...] Rezultat był taki - żadnej choroby psychicznej, osobowość o wybitnie rozwiniętym talencie wybiórczym, sprawność intelektu mierzona, w skali Stanforda-Binet na ok. 45, ale jak stwierdzono, wcale nie znaczy to, że była taka sama w latach jego młodości. Nikifor był już stary, zniszczony ciężkim życiem, zahamowany we wszechstronnym rozwoju przez długotrwałą izolację od otoczenia (bełkot), nastawienie tylko na malarstwo i zaspakajanie podstawowych potrzeb życiowych. (Jego wrażliwość artystyczna, umiejętność rozpoznawania stylów, klimatów malarstwa a nawet dzieł konkretnych mistrzów była, jak mogłem zauważyć, znacznie wyższa, niż badających go specjalistów). Ważne były jednak dwie konstatacje, pierwsza - brak cech chorobowych, druga - przyczyna bełkotu" (Jackowski 1985: 234-235). 
spotkaniu z nami obracał się, śmiejąc i mówił «Nykyfor welki pana»" (cyt. za: Dańko 2003). O analogicznych „słabościach”, wiążących się z jego specyficzną próżnością, mówi też Władysław Krynicki, przez lata dzielący z Nikiforem dom przyznany Łemkom:

Był bacznym obserwatorem życia publicznego i wyższe sfery mu imponowały. Podczas porannej toalety zawsze używał wody toaletowej. Pytałem go, dlaczego się tak mocno kropi. Odpowiedział, że panowie na deptaku tak pachną i on też musi być taki jak oni. Chciał zaistnieć jako osoba z tego samego świata (Krynicki 2018).

Swoim pozaliterackim rejestrem wspomnienie to utwierdza rys portretu wykreowanego przez Szczepańskiego: „Słyszałem o tym nałogu. Kupował perfumy (wybierał je podług kolorów) i zlewał się nimi obficie wśród westchnień zmysłowego upojenia” (Szczepański 1983: 68). Wytrawny pisarz z ujmującą sprawnością literacką sfunkcjonalizował w opisie ów „nałóg” Nikifora: jakby mimochodem, parenezą włączając go w kompleks składników budujących wizerunek uwrażliwionego na barwy malarza: „(wybierał je podług kolorów)”.

Nie może dziwić, że podpowiadane autokreacje Nikifora wiązane są zazwyczaj z kompensacją ( „Może w ten sposób kompensował swoje liczne w życiu upokorzenia...”; „to była raczej sprawa kompensacji niż pogardy” (Jackowski, Jarnuszkiewiczowa 1985: 232, 237), zaś sytuacyjne aranżowanie portretu z koniecznością przystosowania się determinującego przetrwanie ${ }^{24}$.

Analogicznie przedstawia się funkcjonowanie wizerunku Genkova: przy dominującym postrzeganiu i utrwalaniu go jako Genki-wariata (zarazem, dla świadomych skali talentu, „jedynego bułgarskiego geniusza malarstwa”, jak określił go Bakałov), pojawiają się jednak wątpliwości wobec - być może nie tylko instynktownie - kreowanego i wyzyskiwanego odbioru. Cytowane wcześniej pytanie Bakałova jest tu wyraziste: „Szalony, alkoholik, cyklofrenik czy dobry aktor, który potrafi razem odgrywać te marginalne role?". Jak inny to

24 Krauze wzmianki (także anegdotyczne) o mitach na temat ,jurodiwego Nikifora” rozpowszechnianych przez wykluczającą go w odległych latach miejscową społeczność opatruje sugestią, że niektóre z owych zgoła nieracjonalnych uprzedzeń przynosiły malarzowi pożytek, choćby taki: „W Krynicy cieszył się złą sławą. Kobiety na targu opowiadały, że odbiera krowom mleko, uważano go za pasożyta, którego należałoby zaaresztować i wywieźć gdzieś daleko. To akurat mu pomogło. Istniał rozpowszechniony przesąd, że jeżeli źle się potraktuje obcego, odmieńca, to sprowadzi na dom nieszczęście" (Maciejewski 2004: 26). 
wizerunek od Nikiforowego, była mowa wielokrotnie: tekstowe reprezentacje uwidaczniają głównie przeciwieństwa artystyczne i osobowościowe twórców. Wspólnota przeciwieństw zaznacza się w utworach, w których obraz postaci zostaje osadzony w realistycznych kontekstach. Owe realia, ewokowane aluzyjnie bądź werbalizowane wprost, uświadamiają, o jaką stawkę malarze grali swoimi autokreacjami. Naznaczeni osobowościowo, społecznie, politycznie, w warunkach ustrojowych swojej doby grają o sprawy zasadnicze: na równi z egzystencją o możliwość tworzenia, którego imperatyw w sobie nosili (i z którego żyli). Strategie autokreacyjne Łemka i dysydenta, jak podpowiadają to tekstowe portrety, mogły wykraczać poza mechanizmy kompensacyjne. Lista cytacji na poparcie tej myśli jest długa. Niech wystarczą w odniesieniu do Genkova te:

Od późnych lat czterdziestych do końca osiemdziesiątych, często był zatrzymywany przy kongresach врк [Bułgarskiej Partii Komunistycznej - D.O.W.] jako niebezpieczny szaleniec i naruszyciel porządku społecznego. W lagrach, szpitalach dla obłąkanych, klinikach dla alkoholików. [...] Jedyna możliwa pozycja [tłumaczy - D.O.W.], dzięki której możesz pozostać żywy i jednocześnie inny, różny. Być marginesem, wariatem, pijakiem, idiotą i tym wszystkim, co można wpisać w rubryce: „brakuje mu piątej klepki”. Ale ty żyjesz. [...] Gdybym nie zaczął pracować za pieniądze, miałbym gruźlicę. Nie jest trudno zapaść na raka. Zacząłem żebrać, pić i palić przez całą dobę. Materia jest matką. Ona dyktuje warunki, musisz się z nią liczyć. [...] Nauczyłem się, że trzeba iść na drobne kompromisy. Do pracy stosowanej, do wykonywania reklam, okładek. Inaczej gruźlica i umierasz. Nikt nie patrzy na sztukę. Świat nie jest walką. To wojna [...]. Ależ, któż mi przeszkadza. Kto może przeszkadzać drugiemu człowiekowi, jeśli nie umieści go w lagrze lub go nie zabije. Byłem w obozie [pracy - D.O.W.] tylko trzy razy. Niektórych zabijają od razu. A ja przez przypadek miałem szczęście. I nie zabili mnie (Ruenov, dostęp 2020).

Najbardziej liczący się [wówczas w Bułgarii - D.O.W.] psychiatra, prof. Ivan Temkov, poręczał całym swoim autorytetem i pozycją, że Genko Genkov nie ma schizofrenii. Potwierdzał to dr Cheszmedżiev: „Powinien zostać w domu i malować. Dlaczego wysyłacie go tutaj, żeby tracił czas?” (Petkova, dostęp 2020).

Jak sugerują komentarze, też Nikifor - choć oczywiście nie prowokował jak Genkov o ogromnym politycznym temperamencie - miał mieć świadomość 
wpisywania się w asekurujący go wizerunek upośledzonego umysłowo niemoty obdarzonego talentem. Znaczący epizod odsłania ks. Wiesław Dziubina, będący w latach czterdziestych proboszczem w krynickiej parafii greckokatolickiej (i spowiednikiem religijnego Nikifora): „Spotkaliśmy się po latach, kiedy został Nikiforem Krynickim. Powiedziałem wówczas do niego: «Wy się nazywacie Drowniak, a nie Krynicki». Wtedy odpowiedział, że wie, ale nie przyznaje się, bo nie jest głupi i nie chce siedzieć w kryminale” (cyt. za: Dańko 2003). „Oficjalnie” przyznany status żebraka (zaskakujący Zachodnią Europę paradoksalnością $\mathrm{w}$ odniesieniu do ustrojowych regulacji w $\mathrm{PRL}^{25}$ ), który Nikifor wypełniał nawet wtedy, gdy już nie musiał, dawał mu jakąś osłonę przed restrykcjami, dla Łemka tym groźniejszymi. Śladów realnych konsekwencji „systemowej czujności” wobec niego zachowało się niemało, jak choćby ta notka milicyjna z początku lat pięćdziesiątych:

Malarz Nikifor (ps. Matejko) włóczy się po wszystkich ruchliwych ulicach m. Krynicy [...], uprawia proceder żebractwa wystawiając przy tym swą sztukę malarską, stwarzając przy tym niekorzystny aspekt polityczny [...], przynosi olbrzymie szkody polityczne i moralne (cyt. za: Kwaśniewski 2000).

Jednym $\mathrm{z}$ istotnych miejsc wspólnych w literackich i paraliterackich reprezentacjach Genki Genkova i Epifaniusza Drowniaka są sekwencje ilustrujące proces twórczy obu artystów (o czym była mowa i co jest zarazem przypisane ekfrazom i hypotypozom). Niejednokrotnie eksponowane są również elementy kontekstu sytuacyjnego malowania i sprzedawania przez nich prac: otoczenie, publiczność, wygląd i zachowania malarzy, także wiążące się z tym rytuały. Są one specyficzne dla każdego z nich wśród publiczności, niemniej powtarzalne i nawet kiedy aktywizowane selektywnie, spontanicznie i w różnicujących wariantach, stają się rozpoznawalnym elementem zdarzeń. Oto Nikifor rozkładający na murku swoje „talizmany”: akwarelowe farbki, list proszalny, kasetkę z obrazkami na sprzedaż, siadający w charakterystycznej pozie, sprawiający wrażenie (często odnotowywane), jakby nie zwracał uwagi na tłumek gapiów, na ich reakcje - a przecież je animował. Od interakcji zależało wiele, trzeba było zaistnieć, przyciągnąć uwagę publiczności i tę poruszyć - obrazki

25 W przywoływanej już recenzji z „L’Express” (23.04.1959) o nagłówku „Genialny kloszard polski Nikifor” stoi: „Ma twarz przebiegłą bezzębnego żebraka. Jest zawsze źle ogolony. Źle mówi, jest prawie zupełnie głuchy i w kraju, gdzie żebractwo jest surowo zakazane, ma pisemne upoważnienie do uprawiania swej «działalności»" (Rydzyńska i in. 2018: 91). 
należało sprzedać. Ślinił pędzelek, przybijał swoje słynne i wymienne pieczątki na odwrocie kartonika, ustalał ceny, karmił bułką swojego psa Hauko itd. ${ }^{26}$ „Genko-wariat” oddziałuje inną ekspresją, inne też są jej symptomy podczas malowania i sprzedaży. Niemniej, stymuluje swoich odbiorców tu i teraz ${ }^{27}$, wciąż dynamiczny, nawet ostentacyjny. Niezależnie od różnicy poetyk utrwalona w tekstach specyfika „trybu pracy” obu malarzy i jej okoliczności stwarza pole dla ujrzenia Nikifora i Genki-wariata jako performerów. Tak pozwalają się interpretować i w swojej sztuce, i w życiu, gdy jedno i drugie po wielekroć uzyskiwało postać żywego przedstawienia. Samo w ich wydaniu malowanie, jego akt, gesty, wygląd, mowa ciała, którą manifestowali swoją idiomatyczność - wszystko to składało się na występ przed publicznością z sofijskich ulic i krynickiego deptaka, generowało żywe zdarzenie artystyczne. W tej zaś artystycznej sytuacji obecność milczącego lub bełkoczącego Łemka czy bez

26 Andrzej Banach pisze: „Nikifor wiedział, że ludzie na ulicy, przechodzący obok jego pracowni, nie mają dużo czasu, są zajęci czym innym, że spojrzenie, które rzucają na jego obrazek jest krótkie, roztargnione, nieuważne, święci, do których się zwracał i malował, także nie mają dużo czasu. [...] Czarodziej doskonały, znał siły, którymi władał i moce, z którymi walczył. Przeciwnikiem jego była organizacja, każda straż porządkowa prześladująca włóczęgów, żebraków, ludzi bez zajęcia. Wobec niej Nikifor musiał się wykazać swoim stanowiskiem. [...] Talizmany swoje nosił więc przy sobie. Ubrany na czarno, w białej koszuli, z czarną krawatką i w kapeluszu czarnym, miał przy sobie, pod lewą ręką, kasetę oszkloną ze swoimi obrazkami. Były one jego zaklęciem, modlitwą zwróconą do władz niebieskich i ziemskich. Do ziemskich przede wszystkim” (Banach 1984: 25-26). Eugeniusz Niemiec rekonstruuje zaś takie sytuacje: „Przygotowując się do malowania nowego obrazka, najpierw wybierał kawałek papieru lub tektury, potem mozolnie na odwrocie pisał cenę: 100 zł lub 50 zł, przybijał dużą, okrągłą pieczęć z napisem «Nikifor-Matejko», a dopiero potem odwracał papier i zabierał się do malowania. Taką procedurę stosował głównie wtedy (ale nie tylko), gdy ktoś chciał zamówić obrazek. Mistrz najpierw pokazywał mu cenę, a jeśli ta była akceptowana, to przystępował do malowania” (Niemiec, dostęp 2020).

27 Ruenov o interakcjach Genkova przy pracy: „Jest gotowy do walki. Natychmiast. Nie wiem, czy go użył, czy to naturalny stan, czy lipcowy upał zmiękczył jego mózg, czy wszystko to razem. Godzilla nie może milczeć” (Ruenow, dostęp 2020). W innym tekście: „Zza rogu dobiegł ochrypły głos. Odwracamy się - przed sklepem «San Stefano» i «Szejnovo» siedzi Genko z dwoma obrazami, po jednym w każdej ręce. [...] Podchodzimy. «Wypróbuję te dwa kicze» - Genko podnosi płótna. Były to piękne pejzaże, w jego charakterystycznym stylu, z czerwono-fioletowymi odcieniami. Obydwa były nadal mokre i wydawało się, że je trzyma, żeby niczego nie dotykały, bo farby olejne jeszcze nie wyschły. Genko niósł płótna, a Stoyan i ja śmialiśmy się z tego, jak sprzedawał obrazy [...] bez targowania się, po stałych cenach" (Bakałov, dostęp 2020). 
ustanku gadającego Genki-wariata sytuowała ich jako podmioty i przedmioty zdarzenia. Demonstrowali się jako twórcy i zarazem sama materia sztuki, gdy wywoływali i pobudzali publiczność (tę przyjezdną nawet Nikifor, do którego miejscowi już się przyzwyczaili). Boczev napisze: „wytrwale i z oddaniem, Genko Genkov malował tak radykalnie, z taką bezlitosną, nieugaszoną pasją, że sam stał się artefaktem” (Boczev, dostęp 2020). Choć najpewniej należy odnieść tę konstatację do (intencjonalnej u Boczeva) integralności malarza i jego dzieła, to wydźwięk frazy jest symboliczny także dla funkcjonowania Genka właśnie jako performera. Podobnie jest w przypadku Nikifora, bo obaj komunikowali ${ }^{28}$ się na co dzień z publicznością w „występach na żywo”, a te zawierały zarówno działania spontaniczne, jak odgrywanie roli, różnych zresztą ról, na czele z tą wykluczanego i niekonwencjonalnego twórcy. Ustalenie granicy pomiędzy tym, co było dla nich naturalne, a co inscenizowane, jest niemal niemożliwe. Bywali w swoich „ulicznych przedstawieniach” jak performerzy: uzależnieni od publiczności zdolnej do interpretowania ich gestu, wyglądu, mowy ciała, do pojmowania (choćby instynktownie) ciągłego dialogu tego, co wewnętrzne, z tym, co zewnętrzne, gdy projekcją jednego i drugiego staje się ciało w ruchu, w pozie. W codziennych okolicznościach występy Nikifora i Genkova stawały się żywym, interakcyjnym przekazem - tu i teraz, w nieformalnej „zmowie” z publicznością. Byli od niej uzależnieni nie tylko bytowo. Pisząc o performansie, Richard Bauman dowodził, że nie musi istnieć wyraźna różnica, także pod względem scenografii, pomiędzy tym, co codzienne, a tym, co inscenizowane. Sugerował również, że występ to „wzmocnienie” intensywności komunikacji, koncentrujące uwagę na samym jej procesie, na użyciu języka i geście (Bauman 2012).

Rzecz jasna, pozostaje świadomość, że w pewnym sensie i Nikifor, i Genko-wariat byli w swojej egzystencji, w twórczej pracy „skazani na performans”, nie była to kwestia dobrowolnego wyboru. Decydowały determinacje: własnymi ułomnościami, kontekstami społeczno-politycznymi, warunkami bytowymi,

28 „Termin performance oznacza proces społeczny (komunikacyjny). Wymaga publiczności i w tym sensie bazuje na interpretacji. Interpretacja dotyczy znaczeń. Innymi słowy, sztuka performance’u jest formą retoryki, retoryki gestu, w której, ogólnie mówiąc, cielesne ruchy i znaki (w tym użycie głosu) dominują nad innymi postaciami znaków komunikacyjnych, takimi jak język czy ikonografia. Takie użycie ciała (które jest rzecz jasna kluczowe dla sztuki performance’u) [...], bazuje na zdolności odbiorców do postrzegania go zarówno jako przedmiotu (erotycznego, atrakcyjnego, odpychającego, społecznego), jak i podmiotu (to znaczy przedmiotu świadomie ukształtowanego, przedmiotu posiadającego znaczenie). Z retorycznego punktu widzenia sztuka performance'u to sztuka nie grania, lecz pozowania" (Frith 2011: 279-280). 
zresztą uzasadnień jest więcej. Wykluczani, stygmatyzowani - performowali, wywołując reakcje, od których zależeli. Nie do rozstrzygnięcia, bo nie do przewidzenia w horyzoncie performansu, zawsze obarczonego ryzykiem nieprzewidywalnej, bo spontanicznej odpowiedzi publiczności, jest kwestia, czy programowali efekt akurat przez siebie oczekiwany w danych okolicznościach. Podobnie nie do rozstrzygnięcia pozostaje, na ile, jeśli w ogóle, świadomie stawali się performerami (w swojej) codzienności. Znajdując się w autopojetycznej pętli feedbecku ${ }^{29}$ (Fischer-Lichte 2008: 29), konstytuowali swoją tożsamość w nieustannej relacji zwrotnej. Codzienny performans (performans ich codzienności) stymulował także reakcje ich samych, utrwalające się z czasem w powtarzalne zachowania. Wywołując afektywny odbiór publiczności, uzyskując fortunny efekt, odkrywali sprawczość działań i w naturalny, ludzki sposób ulegali pokusie repetycji sprawdzonych zachowań. W odniesieniu do życiowych i malarskich losów Genkova i Nikifora, „performuj albo żyj” przestaje brzmieć jak chwytliwa przenośnia, zaczerpnięta z głośnej książki Jona McKenziego (McKenzi 2011).

Literackie utwory rezonujące pracami i osobowościami tych malarzy nie są nadzwyczaj liczne. Znacznie więcej jest ekfraz krytycznych, z przewagą utrwaleń Łemka. Wśród hypotypoz poetyckich najciekawszy wydaje się wciąż wiersz Zbigniewa Herberta Nikifor, który stawał się już przedmiotem interpretacji ${ }^{30}$. Nie powielając zatem wartościowych ustaleń, chciałabym dodać do

29 Termin wprowadzony przez Erikę Fischer-Lichte, stanowiący konsekwencję definiowania na nowo (w świetle performatyki i wobec performansu) relacji między wykonawcami a widzami. Fischer-Lichte pisze, że prowadziło to do odrzucenia „znakowego charakteru działań i ich możliwych znaczeń na rzecz specyficznej cielesności i jej oddziaływania na wszystkich uczestników, to znaczy ich fizjologicznych, afektywnych, energetycznych i motorycznych reakcji, jak również warunkowanych przez nie [...] sensualnych doświadczeń" (Fischer-Lichte 2008: 29). Wolno zarazem powiedzieć, że autopojetyczna pętla feedbacku oscyluje między pozycją podmiotu i przedmiotu (przeskakuje z jednej na drugą i z powrotem). „Podmiot” i „przedmiot” nie tworzą tu opozycji, ale oznaczają różne stany czy pozycje oglądającego i oglądanego, które można zajmować kolejno, czasem nawet jednocześnie. Może się tak dziać również w życiu codziennym, kiedy doświadczamy siebie samych w akcie percepcji - jako „aktywnie oglądających” i równocześnie determinowanych przez to, co oglądamy, będąc wówczas zarazem podmiotami i przedmiotami.

30 Wykładnię tego wiersza, niewłączonego przez Herberta do żadnego tomu poetyckiego, przedstawiła Joanna Adamowska w kontekście pozostałych dwóch jeszcze tekstów Herberta, „transparentnie” mu poświęconych. To felieton Wywiad z Nikiforem (opublikowany po raz pierwszy w 1950 roku w „Tygodniku Powszechnym” (nr 43, s. 8), notabene jako debiut Herberta na łamach pisma) oraz artykułu Nikifor (pierwodruk 
nich dwie sugestie analityczno-interpretacyjne, być może istotne w kontekście przedstawianych tutaj ujęć Nikifora i jego malarstwa. Kwestia pierwsza wiąże się $\mathrm{z}$ analogią, która zarysowuje się pomiędzy tym wierszem Herberta a jednym z jego kanonicznych utworów Dlaczego klasycy. W świetle właśnie kanoniczności tamtego tekstu, jak też „wysokiego” bohatera lirycznego proponowane zestawienie może powodować tym większe kontrowersje. Chcę więc raz jeszcze podkreślić, że dostrzegam je głównie dzięki łączącej te wiersze paraleli konstrukcyjnej. Wynikające z niej sensy uwypuklają się dwukrotnie: w argumentacji lirycznych bohaterów, motywującej fakt, że znaleźli się w opresywnej sytuacji, i w puencie utworów.

Każdy z nich domyka interwencyjna koda, wyrażająca niepewność o losy sztuki współczesnej w warunkach wydziedziczania z porządku śródziemnomorskiego. Wielokrotnie cytowana puenta (ostatnia numerowana, trzecia część wiersza) Dlaczego klasycy, stroniąc od zabrudzenia poezji eksplicytnym dydaktyzmem, zawiera przestrogę: „jeśli tematem sztuki / będzie dzbanek rozbity / mała rozbita dusza / z wielkim żalem nad sobą // to co po nas zostanie / będzie jak płacz kochanków / w małym brudnym hotelu/ kiedy świtają tapety" (Herbert 2011a: 360). W wierszu Nikifor (jak wcześniej, w części ostatniej i także opatrzonej numerem trzy) również zawarta jest przestroga dotycząca losów sztuki współczesnej, zwłaszcza tendencyjnej. Obrazek krynickiego Matejki, z ubóstwa tworzony na zużytych kartkach uczniowskich zeszytów, uzyskuje strukturę palimpsestową. Jedna z jej odsłon to prześwitujące przez mokry papier „szkolne wypracowanie / na temat / Smutne Życie / Wiejskiego Proletariatu / w Bardzo Zamierzchłych Czasach” (Herbert 2011b: 158). W puencie tego wiersza w miejsce przepowiedni z Dlaczego klasycy pojawia się hypotypiczna wykładnia malarstwa Nikifora, która jeszcze daje nadzieję, że „to co po nas zostanie” będzie czymś więcej niż „wielkie szpiczaste litery” na zadany temat (co warto czytać metonimicznie, bo i wizualizacja kroju liter, i obowiązkowe tematy odsyłają aluzyjnie do ówczesnych czasów). Jest także w puencie niepewność, czy delikatna materia prawdziwej sztuki zdoła przetrwać i zrównoważyć tę drugą, żałosną stronę, która się przebija do obrazu, na ile twórczość marginalizowanych artystów, będąca czymś więcej niż nieudolne wypracowanie ${ }^{31}$, może ocaleć

w czasopiśmie „Twórczość” w 1957 roku (nr 10-11, s. 239-240)). Obydwa te teksty miały charakter interwencyjny, w takiej też konwencji są utrzymane (Adamowska 2018).

31 W opowiadaniu Biskup jedzie przez morze Szczepański, przeciwstawiając wartość malarstwa Nikifora sztuce współczesnej, zwłaszcza tworzonej na zadany temat, sarkastycznie podsumował i artystów, i sztukę: „I jako ostanie wyzwanie artysty: «Patrzcie, stworzyłem coś, co absolutnie nic nie znaczy!»” (Szczepański 1983: 73). 
i powiedzieć o nas kiedyś coś więcej i piękniej? Uobecnienie Nikifora w procesie twórczym nie pozostawia tu wątpliwości co do wysokiej rangi jego malarstwa. Nadaje mu Herbert wymiar sprawczy - nawet wzbudzający obrzydzenie gest ślinienia pędzla i dotykania kamyków zostaje skojarzony z fragmentem Ewangelii św. Jana opisującym uzdrowienie niewidomego przez nałożenie mu na oczy błota wymieszanego ze śliną Chrystusa. Sam zaś Nikifor okazuje się poruszycielem, co jest odesłaniem do Pierwszego Poruszyciela („przedtem / trzeba pędzel poruszyć / to znaczy poślinić”). Wiersz w obliczu puenty nabiera charakteru interwencyjnego nie tylko w odniesieniu do Nikifora, którego trzeba wesprzeć. Podobnie jak w Dlaczego klasycy, puenta interpeluje współczesną sztukę, pyta o jej tożsamość wobec sztuki prawdziwej, która przetrwała wieki, tworzonej nie „na zadany temat”. Kreśli scenariusz dalszych jej losów i dziedzictwa, jakie pozostawimy po sobie. Obrazki Nikifora, ukazane jako kreacje nieskażonej wyobraźni, radośnie twórcze i stwarzające, w zestawieniu z sensami puenty Dlaczego klasycy uzyskują tym wyższą waloryzację: to, co po nas zostanie (jeśli ocaleje), nie będzie tylko „rozbitym dzbankiem”, co nie nosi już sensu, jak nie może nosić wody. Nie musi być też ersatzem wspaniałego świtu, który w Dlaczego klasycy zastępują świtające tapety.

Druga analogia, jaką dostrzegam pomiędzy tymi wierszami Herberta, dotyczy formuł argumentacji postaci lirycznych: arystokratycznego Greka, najwybitniejszego starożytnego historyka, który po przegranej bitwie został wygnany na dwadzieścia lat $\mathrm{z}$ Aten - i ułomnego, poddawanego drwinom, wreszcie prymitywnego malarza, Łemka, także tracącego za sprawą polityki swoją wspólnotę. W obu utworach owe autoprezentacje są pośrednie, jakby z drugiej ręki, co także je łączy: argumenty Tukidydesa podane są w mowie pozornie zależnej („mówi tylko / że miał siedem okrętów / była zima / i płynął szybko", Herbert 2011a: 360), argumenty Nikifora zawarte są w liście proszalnym pisanym cudzą ręką. W obu przypadkach konstrukcja opiera się na enumeracji. Ascetyczne wyliczenie powodów, które sprawiły, że obaj bohaterowie liryczni znaleźli się w sytuacji opresywnej, wskazuje na honor, męską (i mężną) przyzwoitość. Ona zostaje nawet wskazana wprost w wierszu Nikifor: „całość kończy / męskie cześć / jakby się wstydził / że za dużo powiedział” (Herbert 2011b: 157). Zobrazowany list żebraczy nieuczonego prymitywa, konstrukcyjnie paralelny wobec mowy Tukidydesa, uzyskuje nobilitację. Analogia podważa wstydliwość czy podejrzenie o nieprzyzwoitość zawartych w nim próśb, podnosząc je do rangi konieczności warunkującej malowanie. Nawiązująca się między wierszami paralela wzmacnia nobilitację owego listu, który w Nikiforze uszlachetniła sama stylistyka: Herbert nazywa go „prostą inwokacją”, zaś nieudolne sformułowanie - „małym sofizmatem”. Dochodzi tu do Herbertowskiej konfrontacji 
„obszaru dziedzictwa” z „obszarem wydziedziczenia”. Partię utworu skupioną na postaci Nikifora domyka puenta akcentująca jego godność. Zarazem zostaje uchylony dysonans pomiędzy jawnym faktem żebrania a zażenowaniem Nikifora, jego - mimo ograniczeń - „męską” przyzwoitością. Wydaje się, że paralela konstrukcyjna zawiązująca się pomiędzy wierszami tym wyraziściej ujawnia optykę Herbertowskiej kreacji Nikifora.

Dotychczasowe interpretacje uobecnienia malarza w tym wierszu warto poszerzyć także o stylizację hagiograficzną. W całości będąc utworem hypotypicznym, raczej reprezentującym charakterystyczne cechy stylu Nikifora i ideę jego przedstawień niż konkretny obraz ${ }^{32}$, tekst uruchamia w konstrukcji lirycznego bohatera komponenty hagiograficzne ${ }^{33}$. Artysta jest tu: ubogi, prosty, uczciwy, wpatrzony w niebo (świetliste na jego obrazku) i przenoszący je motywami malarskimi w świat ludzi, żyjący w ascezie, cierpiący samotność (,jest sierotą"), dobrodusznie naiwny, a zarazem mężnie wypełniający powołanie, swoją sztuką („okruchami tęczy”) ponawiając, przedłużając boskie przymierze z ludźmi, będący w ziemskim planie „poruszycielem”. Nobilitacja wykluczanego Łemka i jego naiwnej sztuki dokonuje się zatem i w tym aspekcie. Na marginesie już tylko dopowiem, iż z podobną stylizacją - z dość wyraźnym odniesieniem do Szymona Słupnika - spotkamy się w wierszu Harasymowicza Drowniak Netyfor. Czytelne jest to zwłaszcza w drugiej jego strofie: „Na drzewie świata szumiącym / Zawieszono mu budkę zieloną / Tam sobie gniazdko umościł / ustrojony złotą koroną" (Harasymowicz 1986: 130).

W eseju Dimitra Boczeva Khudozhnikŭt i kanarcheto (Artysta i kanarek) w zgodzie z poetyką literackiej ekfrazy występuje sugestywnie upodmiotowiona interpretacja zarówno wybranych płócien Genki Genkova („sur des idées des tableaux”) i jego idiomu twórczego, jak i samej postaci malarza („sur une image de l'artiste"). Obydwa aspekty przenikają się, wzajemnie się oświetlając. Esej jest erudycyjny, bogato inkrustowany odwołaniami do europejskiego malarstwa, do

32 Adamowska $\mathrm{w}$ wartościowej i bogatej w konteksty interpretacji przyjmuje, że obrazem opisywanym w trzeciej części wiersza jest słynny Nikiforowy Autoportret w trzech postaciach. Mając go przed oczami, tym bardziej nie podzielam tego przekonania, pozostając równocześnie w zgodzie z wyrażoną o zdanie wcześniej tezą badaczki, iż w tej części utworu mamy do czynienia z „syntetyczną ekfrazą obrazów krynickiego malarza” (Adamowska 2018: 100). W moim rozumieniu chodziłoby tu raczej o hypotypiczność, ale to już kwestia drobiazgowych uściśleń i wyborów teoretyczno-terminologicznych. Notabene, są one nierzadkie w powiastkach o Nikiforze. We wspomnieniach kryniczan funkcjonowała na przykład opowieść o jego niemal biblijnych narodzinach w drewnianej szopie. Powiadano, że matka małego Nikifora, wskazując na obrazy świętych w cerkwi, mówiła niewyraźnie: „To twój ojciec”. 
literatury, zawiera rozważania metaartystyczne, które dotyczą m.in. dyspozycji kodów plastycznego i werbalnego do chwytania istoty zjawisk, do ekspresji twórcy, wreszcie do oddziaływania na odbiorcę. Nierzadkie to w ekfrastycznych utworach, że zafascynowani malarstwem literaci to jego środkom wyrazu przypisują wyższość. Sami, „skazani na słowa”, odczuwając ich opór i niesatysfakcjonującą transmisję subiektywnego doświadczenia - jak Boczev przy werbalnej reprezentacji obrazów Genki-wariata - tym bardziej dowartościowują kreacje malarza w posłusznym jego intencjom i talentowi języku plastycznych form. Fakt, że ten esej pochodzi z książki o wieloznacznym tytule Nesygłasni dumi (jest tu gra językowa, którą można przetłumaczyć jako „słowa sprzeciwu” lub „nieposłuszne słowa”, ale też „nie zgadzam się ze słowami”), stwarza dodatkowy kontekst semantyczny dla uobecnień Genkova i jego malarstwa, jego postawy, jego kompozycji odczytywanych jako nieustanna kontestacja powszechnych reguł, przełamywanie ich, żeby zachować i wyrazić własny światoobraz. Bliskie to sensom zawierającym się w przywoływanym tytule monografii krytycznej Jankova: Bunt w kolorach. W eseju Boczeva wiele jest miejsc eksponujących i wysoko wartościujących ową niezależność Genki-wariata, odbitą w jego sztuce. Autor wprowadza cytaty poetyckie, pełniące funkcję uwznioślającą. Traktując język poezji jako najbliższy malarstwu, zdolny do uobecnienia jego kwintesencji, zapośrednicza własne reprezentacje w utworach, które w swoim macierzystym kontekście nie odnoszą się do Genkova. Rekontekstualizując je, równocześnie podnosi rangę wykluczanego artysty i jego, nie w pełni wówczas docenianej, sztuki. Nieprzypadkowy jest tu wybór poetów, którzy są cenieni w Bułgarii. Znaczące jest nazwisko - jak i sam utwór - Nikołaja Kynczewa ${ }^{34}$

34 Jest jakoś znaczące, że Kynczev nie tylko tłumaczył poezję Herberta na bułgarski (jak również m.in. Henriego Michaux, Ezry Pounda, Clauda Estebana, Kennetha Whitea), ale łączyła ich także znajomość i korespondencja. W niniejszym artykule „spotkanie” poetów wywołane ich utworami, które (choć w przypadku Kynczeva raczej nieintencjonalnie) odnoszą się do długo marginalizowanych artystów, nawet stygmatyzowanych, nabiera dodatkowych sensów. O samym zaś Kynczewie tak pisze Kalina Bahneva: „Kynczew jest znany nie tylko z intelektualnej poezji, lecz również ze swojej dumnej postawy obywatelskiej. Wspomnę tylko, że przez dwanaście lat (od 1968 do 1980 r.) objęty był zakazem publikowania wierszy. Jest to bodajże jedyny nasz [bułgarski - D.O.W.] twórca, który wyraził niezgodę na reżim socjalistyczny, a także utarte formy egzystencji. W niemalże stoicki sposób odmawiał przyjęcia jakiejkolwiek posady etatowej, nie brał żadnej chałtury i utrzymywał się przez całe życie jedynie z honorariów autorskich. «On nas zadziwiał przez wszystkie te lata: czy naprawdę żyć można, nie idąc absolutnie na żaden kompromis? Czy mogła zawsze i wszędzie na pierwszym miejscu stać Poezja?» - pisał po jego śmierci krytyk Michaił Nedełczew”. I dalej: „[Kynczewa zbiory 
Twoje życie, który w eseju staje się analogonem świadomej siebie, niezależnej osobowości Genkova. Boczev słowami poety uwzniośla ją tak: „Będziesz miał prosty chód drzewa / Co kroczy wciąż wyżej [...] / znasz bowiem drogę / znasz drogę / Drogę" (cyt. za: Boczev, dostęp 2020) ${ }^{35}$. Występujący w wierszu symbol drzewa wiąże się z ulubionym motywem malarskim Genkova, do którego eseista wielokrotnie nawiązuje.

Drugi z wprowadzonych do eseju Boczeva wierszy to Obraz Nikołaja Koleva i to on - zgodnie z brzmieniem tytułu - ma oddać, celniej niż język eseju, fenomen płócien Genki Genkova. One - zachowując w sobie „żywe życie”, sugestywne piękno - wybijają z martwoty nawet zimne ściany, teraz czujące ciepło i kształt (wciąż „żywego” na obrazie) ciała: „Na ścianie powiesiłem obraz nagiej kobiety. / [...] a oto biedna ściana zapłakała, / że piersi tej kobiety były okrągłymi księżycami, / a piersi wszystkich ścian są płaskie i chłodne” (cyt. za: Boczev, dostęp 2020) ${ }^{36}$.

Wgląd w polskie i bułgarskie teksty ekfrastyczne, niejednorodne formalnie i co do wagi, a zogniskowane wokół postaci i dzieł artystów o podobnym statusie w swoich rodzimych kontekstach, raz jeszcze kieruje myśl ku transgresji. Wydaje się, że stanowi ona wspólny mianownik literackich, krytycznych i paraliterackich kreacji Nikifora oraz Genki-wariata. Jeśli transgresja nie jest w utworach wprost artykułowana, jest ona stale ewokowana przez piszących o nich. Autorzy postrzegają tych twórców jako ludzi permanentnie i spektakularnie przekraczających granice: wykluczenia potęgowanego odmiennością i ułomnością, biograficznych traum i powodowanych nimi wewnętrznych barier, społecznych norm i konstruktów mentalnych, systemowych ostracyzmów. Przede wszystkim zaś jako artystów, którzy świadomie eksperymentując bądź (jak Nikifor) korzystając $z$ dostępnych naiwnych form wyrazu, przyjmowanych jako rewelatorskie - radykalnie wykraczają własną sztuką poza funkcjonujące w niej tendencje. Dynamizując ich granice, przesuwają je i poszerzają swoim malarstwem, zarazem owe granice uwyraźniając. Tak byli odbierani, tak odczy-

wierszy - D.O.W.] wydano w Polsce, Niemczech, Holandii, Austrii, Serbii, Czechach, Gruzji, we Włoszech, Hiszpanii, usa i Francji. W 2001 r. Kynczew został wybrany na członka Światowej Akademii Poetów" (Bahneva, w druku).

Autorem tłumaczenia jest Wojciech Gałązka, przekład widnieje na stronach internetowych tego bułgarysty i tłumacza. Dalszy ciąg wiersza jest następujący: „Głód twych owoców zatrzyma wielu, / Ale nie staniesz się dłużnikiem / Takich wędrowców. / Nie, nigdy głód. / Raczej miłość. / Ale zaznałeś / Wielokrotnych objęć węża!".

36 Także ten liryk podaję za esejem Boczeva, w przekładzie własnym przy wsparciu prof. Kaliny Bahnevej. 
tywana jest ich twórczość: transgresje „praktykowane” przez Genkę Genkova i Epifaniusza Drowniaka w życiu i sztuce, poddane interpretacjom pisarzy w „werbalnych reprezentacjach wizualnych reprezentacji” (Heffernan 1991: 299), ukazują się jako zjawiska paralelne w kulturze Europy Środkowej.

\section{| Bibliografia}

Adamowska Joanna (2018), Sens kobaltu. Zbigniewa Herberta i Tadeusza Różewicza spotkania z malarzami, Wydawnictwo Biblioteka Pana Cogito, Kraków.

Bahneva Kalina (w druku), „Nigdy nie jestem tylko tu...” Polsko-bułgarskie zblizenia $i$ konfrontacje.

Bakałov Ivan, Istorii s Genko-Ludiya (Historie z Genką-wariatem/ Wspomnienia o Genku-wariacie), https://preview.tinyurl.com/yywvafdu [dostęp: 16.08.2020].

Banach Andrzej (1959), Pamiątka z Krynicy, Wydawnictwo Literackie, Kraków.

Banach Andrzej (1984), Nikifor, Wydawnictwo Arkady, Warszawa.

Boczev Dimitar, Khudozhnikŭt i kanarcheto, https://preview.tinyurl.com/ y47v5muy [dostęp: 19.08. 2020].

Bauman Richard (2012), Sztuka słowa jako performance, przeł. Grzegorz Godlewski, w: Literatura ustna, red. Przemysław Czapliński, słowo/obraz terytoria, Gdańsk, s. 202-234.

Dahl Władimir Iwanowicz (1882), Tołkowyj słowar’ żiwogo welikorusskowo jazyka, Wydawnictwo księgarni-typografa M. O. Wolfa, S. Petersburg-Moskwa, https://tiny.pl/rnzlb [dostęp: 1.09.2020].

Dańko Ireneusz (2003), Tożsamość Nikifora, „Poznań.Wyborcza.pl., 14.03, https://tiny.pl/rkq4b [dostęp: 20.08.2020].

Dziadek Adam (2004), Obrazy i wiersze. Z zagadnień interferencji sztuk w polskiej poezji współczesnej, Wydawnictwo Uniwersytetu Śląskiego, Katowice.

Dziadek Adam (2006), Apologia twórczej swobody. Eseje Zbigniewa Herberta: opis - uobecnienie - interpretacja, w: Zmysł wzroku, zmyst sztuki. Prywatna historia sztuki Zbigniewa Herberta, cz. II, red. Józef Maria Ruszar, Wydawnictwo Archidiecezji Lubelskiej „Gaudium”, Lublin, s. 30-50.

Dziadek Adam (2018), Ekfraza, w: Ilustrowany słownik terminów literackich. Historia, anegdota, etymologia, red. Zbigniew Kadłubek, Beata Mytych-Forajter, Aleksander Nawarecki, słowo/obraz terytoria, Gdańsk, s. 150-153.

Dwurnik Edward (2005), Krótka historia mojego malarstwa, w: Thanks Jackson. Dwurnik 2001-2004. Katalog wystawy, red. Maria Anna Potocka, oprac. graficzne Rafał Sosin, Bunkier Sztuki, Kraków, s. 91-93. 
Fischer-Lichte Erika (2008), Estetyka performatywności, przeł. Małgorzata Sugiera, Mateusz Borowski, Księgarnia Akademicka, Kraków.

Frith Simon (2011), Sceniczne rytuały. O wartości muzyki popularnej, przeł. Marek Król, Wydawnictwo Uniwersytetu Jagiellońskiego, Kraków.

Genko Genkov e rekord'or za wtora godina (2002), https://tiny.pl/rkhfb [dostęp: 12.08.2020].

Harasymowicz Jerzy (1986), Wybór wierszy, Wydawnictwo Literackie, Kraków.

Heffernan James A.W. (1991), Ekphrasis and Representation, „New Literary History", t. 22, nr 2, s. 297-316.

Heffernan James A.W. (1993), Museum of Words. The Poetics of Ekphrasis from Homer to Ashbery, The University of Chicago Press, Chicago.

Herbert Zbigniew (2001), Węzeł gordyjski oraz inne pisma rozproszone 1948-1988, Biblioteka „Więzi”, Warszawa.

Herbert Zbigniew (2011a), Wiersze zebrane, oprac. Ryszard Krynicki, Wydawnictwo a5, Kraków.

Herbert Zbigniew (2011b), Utwory rozproszone (Rekonesans), oprac. Ryszard Krynicki, Wydawnictwo a5, Kraków.

Jackowski Aleksander (2010), Świat Nikifora, słowo/obraz terytoria, Gdańsk. Jackowski Aleksander, Jarnuszkiewiczowa Jadwiga (1985), Notatki o Nikiforze, „Polska Sztuka Ludowa - Konteksty”, t. 39, z. 3-4, s. 227-238.

Janion Maria, Rosiek Stanisław, red. (1984), Osoby, Wydawnictwo Morskie Gdańsk, Gdańsk.

Jankov Jordan (2001), Bunt na tsvetovete, Parabola, Sofia.

Jankowicz Grzegorz (2010), Nieobecna ekfraza, w: Kulturowe wizualizacje doświadczenia, red. Adam Dziadek, Włodzimierz Bolecki, Instytut Badań Literackich PAN, Warszawa, s. 210-225.

Karski Bogdan, Nikifor jakiego nie znamy, https://preview.tinyurl.com/y303633q [dostęp: 03.09.2020].

Kolev Nikołaj, Kartina (Obraz), https://preview.tinyurl.com/y47v5muy [dostęp: 19.08.2020].

Krynicki Władysław (2018), Uważali go za głupka. Samotny gruźlik, żebrak bez domu, analfabeta. Jeden z najwybitniejszych prymitywistów świata, rozmawiała Monika Chrobak, „TVP Tygodnik”, 10.08.2018, https://tiny.pl/rkxxq [dostęp: 17.08.2020].

Kwaśniewski Maciej (2000), Malarz i żebrak, „Gazeta Krakowska”, 28.03.

Kynczew Nikołaj, Twoje $\dot{z} y c i e$, https://literaturabulgarska.vilnet.pl [dostęp: 17.08.2020].

Lessing Gothold Ephreim (1962), Laookon albo o granicach malarstwa i poezji. Czesść pierwsza, oprac. Jolanta Maurin-Białostocka, przeł. Henryk Zymon- 
-Dębicki, Zakład Narodowy im. Ossolińskich, Wydawnictwo Polskiej Akademii Nauk, Wrocław-Warszawa-Kraków.

Maciejewski Łukasz (2004), Wolny artysta (rozmowa z Krzysztofem Krauze), „Kino”, nr 6, s. 26-27.

McKenzie Jon (2011), Performuj albo..., wstęp i przeł. Tomasz Kubikowski, Universitas, Kraków.

Mitchell William John Thomas, Ekphrasis and the Other, https://preview.tinyurl. com/r49u2r [dostęp: 6.08.2020].

Mój Nikifor, reż. Krzysztof Krauze, Studio Filmowe Zebra, Telewizja Polska Agencja Filmowa Canal+ Polska, 2004.

Niemiec Eugeniusz, Nikifor, https://tinyurl.com/y5fypvpu [dostęp: 2.08.2020].

Petkowa Marliea, Genko Genkov: alchnostta shte izgde jivota (Chciwość pożre życie), https://tinyurl.com/y25eo7tj [dostęp: 19.08.2020].

Pismo Święte Starego i Nowego Testamentu w przekladzie polskim W. O. Jakuba Wujka S. J. (1962), tekst poprawili oraz wstępami opatrzyli: Stary Testament ks. Stanisław Styś S.J., Nowy Testament ks. Władysław Lohn S.J., wyd. 3 popr., Wydawnictwo Apostolstwa Modlitwy, Kraków.

Riffaterre Michaelle (1994), L'illusion d'ekphrasis, w: La pensée de l'image. Signification et figuration dans le texte et dans la peinture, red. Gisèle Mathieu-Castellani, Presses Universitaires de Vincennes, Saint-Denis, s. 211-227.

Popowski Remigiusz (2004), Starożytny przewodnik po neapolitańskiej pinakotece, w: Filostrat Starszy, Obrazy, przeł., wstęp, komentarz i przypisy Remigiusz Popowski, Prószyński i S-ka, Warszawa, s. 13-87.

Porębski Mieczysław (1962), Sztuka a informacja, „Roczniki Historii Sztuki”, r. 3, s. $44-105$.

Ruenov Ruen, Genko Genkov - Ludiya. Edin bŭlgarski geniǔ v zhivopista, https:// tinyurl.com/y2plxqus [dostęp: 17.08.2020].

Rydzyńska Marta, red., Karpińska Marzena, Jaxa-Chamiec Maria, Pająk Michał, oprac. (2018), Katalog wystawy „Nikifor” Domu Aukcyjnego Polswiss Art, Polswiss Art, Warszawa.

Słodczyk Rozalia (2018), Powrót do ekfrazy. Próba systematyzacji oraz próba typologii, „Teksty Drugie”, nr 5, s. 352-371.

Słodczyk Rozalia (2020), Ekfraza, hypotypoza, przekład. Interferencje literatury i malarstwa w prozie włoskiej i eseistyce polskiej Xx w., Wydawnictwo Uniwersytetu Jagiellońskiego, Kraków.

Słownyk ukrainskoj mowy. Akademiczny tłumaczny słownik 1970-1980, https:// tiny.pl/rnzff [dostęp: 01.09.2020].

Swoboda Bartosz (2011), Zniewalajaca siła ekfrazy (rzecz o zmaganiach słowa i obrazu w poglądach W.J.T. Mitchella), „Przestrzenie Teorii”, nr 16, s. 41-50. 
Szczepański Jan Józef (1983), Biskup jedzie przez morze, w: tenże, Rafa, Czytelnik, Warszawa, s. 55-76.

Szerszeń Natalia, Czy prymitywizm może oddać rzeczywistość? Rozważania na marginesie twórczości Nikifora, https://tiny.pl/rkhp5 [dostęp: 05.08.2020].

Wolf Jerzy (1938), Malarstwo nowego realizmu w Polsce. Nikifor, „Arkady”, nr 3, s. 24-30.

\section{| Abstrakt}

Danuta Opacka-Walasek

Nikifor i „Genko-wariat”. Wgląd w ekfrastyczne transgresje polsko-bułgarskie

Przedmiotem artykułu są ekfrastyczne reprezentacje postaci i malarstwa Epifaniusza Drowniaka oraz Genko Ivana Genkova (nazywanego „Genką-wariatem”), funkcjonujące w rejestrach literackich, krytycznych i publicystycznych. Rewelatorska twórczość, traumatyczne biografie obu artystów posiadają potencjał legendotwórczy; byli oni podobnie stygmatyzowani, wykluczani przez swoją odmienność. W ustrojowych warunkach powojennych Polski i Bułgarii podlegali licznym deprecjacjom jako kłopotliwi politycznie Łemko i dysydent, podczas gdy ich obrazy uchodziły za paszporty tych krajów do światowej sztuki. Ekfrastyczne i hypotypiczne uobecnienia malarstwa, osobowości („sur une idée du tableau”, „sur une image de l’artiste”) Nikifora i Genkova są w artykule podstawą analizy porównawczej i interpretacji m.in. w aspektach wykluczenia, transgresji, performansu.

Słowa kluczowe: Nikifor; Genko Genkov; hypotypoza; wykluczenie; transgresja; performans

\section{| Abstract}

Danuta Opacka-Walasek

Nikifor and Insane Genko. The Insight into the Ekphrastic Polish-Bulgarian Transgressions

The article discusses the ekphrastic and hypotypotic representations of the characters and the paintings by Epifaniusz Drowniak (Nikifor) and Genko Ivan Genkov (known as "Insane Genko") that function in the Polish and Bulgarian literary, critical and publicist registers. Both artists' revelatory bodies of works and traumatic 
biographies have the legend-creating potential; they were similarly stigmatized, excluded because of their otherness, and as a politically inconvenient Lemko and a dissident. Becoming in their lifetime under systemic conditions of post-war Poland and Bulgaria those countries' passports to global art, they were subjects of many depreciations. The literary and paraliterary representations of their paintings, personalities ("des idées des tableaux," "des images des artistes") are interpreted i.a. in the aspects of exclusion, transgression and performance.

Keywords: Nikifor; Genko Genkov; hypotyposis; exclusion; transgression; performance

\section{| Nota o autorze}

Danuta Opacka-Walasek - prof. dr hab., literaturoznawczyni (Uniwersytet Śląski, Instytut Literaturoznawstwa). Autorka licznych interpretacji liryki współczesnej, ważniejsze książki i artykuły poświęciła twórczości Z. Herberta, Cz. Miłosza, S. Barańczaka, zagadnieniom czasu w poezji, mariażom wzniosłości i ironii (m.in.: „...pozostać wiernym niepewnej jasności” Wybrane problemy poezji Zbigniewa Herberta, Katowice 1996; Potega smaku. Zbigniew Herbert, Warszawa 1997; Czytając Herberta, Katowice 2001; Chwile i eony. Obrazy czasu w polskiej poezji drugiej połowy XX wieku, Katowice 2005; Pasaże liryczne, Katowice 2013). Wespół z Piotrem Kilanowskim opracowała pierwszą w języku portugalskim antologię poezji Z. Herberta (Podróż Pana Cogito/A Viagem do Senhor Cogito, Katowice 2016), będącą zarazem śladem praktyki i zainteresowań glottodydaktycznych wiążących się z kilkudziesięcioma seminariami i wykładami o polskiej poezji, przeprowadzonymi w krajach Europy oraz Ameryki Południowej.

E-mail: danuta.opacka-walasek@us.edu.pl

ORCID: 0000-0001-9104-0590 
